Article

\title{
Bifunctional Electrocatalyst of Low-Symmetry Mesoporous Titanium Dioxide Modified with Cobalt Oxide for Oxygen Evolution and Reduction Reactions
}

\author{
Mabrook S. Amer ${ }^{1}{ }^{(}$, Mohamed A. Ghanem ${ }^{1, *(1)}$, Prabhakarn Arunachalam ${ }^{1}{ }^{1}$, \\ Abdullah M. Al-Mayouf ${ }^{1}$ and Sultan M. Hadadi ${ }^{2}$ \\ 1 Electrochemical Science Research Chair (ESRC), Chemistry Department, College of Science, King Saud \\ University, Riyadh 11451, Saudi Arabia; msamer@ksu.edu.sa (M.S.A.); parunachalam@KSU.EDU.SA (P.A.); \\ amayouf@ksu.edu.sa (A.M.A.-M.) \\ 2 King Abdulaziz City for Science and Technology, Riyadh 11442, Saudi Arabia; shsdadi@kacst.edu.sa \\ * Correspondence: mghanem@ksu.edu.sa; Tel.: +966-114670405
}

Received: 10 September 2019; Accepted: 2 October 2019; Published: 8 October 2019

\begin{abstract}
Hybrids of low-symmetry (disordered) mesoporous titanium dioxide modified with different weight ratios of cobalt oxide nanoparticles $\left(\mathrm{Co}_{3} \mathrm{O}_{4}(x) / l s m-\mathrm{TiO}_{2}\right)$ are prepared using a one-pot self-assembly surfactant template. The physicochemical characterization of $\mathrm{Co}_{3} \mathrm{O}_{4}(x) / l s m-\mathrm{TiO}_{2}$ hybrids by scanning and transmission electron microscopy, $\mathrm{X}$-ray diffraction, $\mathrm{N}_{2}$ adsorption-desorption isotherms, and X-ray photoelectron spectroscopy confirm the successful incorporation of cobalt oxide nanoparticles (2-3 nm in diameter) with preservation of the highly mesoporous structure of titanium dioxide substrate. Among these mesoporous hybrids, the $\sim 3.0 \mathrm{wt} . \% \mathrm{Co}_{3} \mathrm{O}_{4} / \mathrm{lsm}-\mathrm{TiO}_{2}$ exhibits the best performance toward both the oxygen evolution (OER) and reduction (ORR) reactions in alkaline solution. For the OER, the hybrid shows oxidation overpotential of $348 \mathrm{mV}$ at $10 \mathrm{~mA} \mathrm{~cm}^{-2}$, a turnover frequency (TOF) of $0.034 \mathrm{~s}^{-1}$, a Tafel slope of $54 \mathrm{mV} \mathrm{dec}^{-1}$, and mass activity of $42.0 \mathrm{~A} \mathrm{~g}^{-1}$ at $370 \mathrm{mV}$. While for ORR, an onset potential of $0.84 \mathrm{~V}$ vs. RHE and OER/ORR overpotential gap $(\Delta \mathrm{E})$ of $0.92 \mathrm{~V}$ are achieved which is significantly lower than that of commercial $\mathrm{Pt} / \mathrm{C}$, hexagonal mesoporous, and bulk titanium dioxide analogous. The $\mathrm{Co}_{3} \mathrm{O}_{4} / l \mathrm{sm}$ - $\mathrm{TiO}_{2}$ hybrid demonstrates significantly higher long-term durability than $\mathrm{IrO}_{2}$. Apparently, such catalytic activity performance originates from the synergetic effect between $\mathrm{Co}_{3} \mathrm{O}_{4}$ and $\mathrm{TiO}_{2}$ substrate, in addition to higher charge carrier density and the presence of disordered mesopores which provide short ions diffusion path during the electrocatalytic process.
\end{abstract}

Keywords: low-symmetry; mesoporous; titanium dioxide; cobalt oxide; oxygen evolution and reduction reactions

\section{Introduction}

The fabrication of effective, highly stable and multi-functional electrocatalysts for oxygen evolution (OER) and reduction (ORR) reactions is in high demand for the commercialization of rechargeable metal-air and Li-ion batteries [1-3], fuel cells [4], and water splitting [5] applications. In particular, the development of highly efficient, stable and dual-functional electrocatalysts for the oxygen evolution $\left(4 \mathrm{OH}^{-} \rightarrow \mathrm{O}_{2}+2 \mathrm{H}_{2} \mathrm{O}+4 \mathrm{e}^{-}\right)$and reduction reactions $\left(\mathrm{O}_{2}+2 \mathrm{H}_{2} \mathrm{O}+4 \mathrm{e}^{-} \rightarrow 4 \mathrm{OH}^{-}\right)$has attracted the interest of scientific researchers, as well as industrial R\&D centers. The OER and ORR processes involve two-electron or four-electron transfer reactions that are hampered by significant overpotential, sluggish kinetics, and instability [6-8]. Thus, the development of highly effective, inexpensive, and bifunctional (active for both the ORR and the OER) electrocatalysts is important for the development of renewable energy technologies. It is well documented that the state-of-the-art catalysts for the OER are Ir- and Ru-based materials, while the Pt-group materials are the most active electrocatalysts for the ORR $[9,10]$. 
However, their high cost, scarcity, weak bifunctionality, and poor stability hinder the applicability of these precious metals in large-scale applications [11]. Consequently, recent research activities have been focused on developing effective bifunctional catalysts with greater performance and cost-effectiveness, and superior durability, for both the ORR and the OER, for widespread applications. Oxides and hydroxides based on transition metals, such as nickel, cobalt, iron, molybdenum, titanium, and tungsten, have emerged as a promising class of noble metal-free material catalysts [12-14]. These earth-abundant materials on various supports have been identified as high activity and stability electrocatalysts for the OER and the ORR under neutral or strongly alkaline conditions [15-21]. For example, nitrogen-doped graphene [22] and carbon nanotubes [23] modified with cobalt oxide nanoparticles hybrids have shown enhanced activity for oxygen reduction and water oxidation reactions. It is believed that the formation of interfacial $\mathrm{Co}-\mathrm{O}-\mathrm{C}$ and $\mathrm{Co}-\mathrm{N}-\mathrm{C}$ bonds and the accompanied synergistic effect are probably responsible for the ORR and OER improved activity [22,23]. Nevertheless, the ORR/OER behavior of the transition metal oxides still requires further improvement to make them highly economical and stable, in comparison to noble metal catalysts, and suitable for commercial applications.

Increasingly more mesoporous materials are being reported as OER/ORR bifunctional catalysts due to their exceptional structural characteristics of narrow pore size distribution, high specific surface area, and well-organized arrangement of mesoporous architectures, which meet the requirements of energy-related conversion, catalysis, adsorption, and sensing applications [24-30]. Furthermore, mesoporous electrocatalysts possess a high population of active surface sites, and the mesoporous network assists the mass transport of reactants and products, in addition to improving the catalytic performance [31,32]. Among these materials, mesoporous $\mathrm{TiO}_{2}$ catalysts have great promise for numerous applications in electrocatalysis and energy-related processes due to good chemical and physical properties, non-toxicity, good biocompatibility, and excellent photoelectric performance [33-36]. Within this context, a considerable number of studies have focused on improving the active sites of the $\mathrm{TiO}_{2}$ structure for the OER. Several researchers have also reported the modification of $\mathrm{TiO}_{2}$-based materials with various cations (such as $\mathrm{Fe}, \mathrm{Co}, \mathrm{Ni}, \mathrm{Mn}$, Bi, etc.) to improve their electronic, chemical, optical, and magnetic properties for a better photo- and electrocatalytic performance in water splitting and energy storage applications [37-43]. In recent relevant work by Hoffmann et al., they reported the cobalt-doped black $\mathrm{TiO}_{2}$ nanotube hybrid that revealed long-term durability for water decontamination and OER applications [44]. However, many of these hybrids still have a shortfall of high overpotential values in comparison with the benchmark catalysts, such as $\mathrm{IrO}_{2}$ and $\mathrm{Pt} / \mathrm{C}$-based catalysts $[36,38,40]$. To this end, our group investigated the preparation of low-symmetry (disorder) mesoporous titanium dioxide $\left(l s m-\mathrm{TiO}_{2}\right)$ with high surface area and a semi-crystalline anatase wall by using a self-assembly surfactant template followed by a two-step annealing process. It was shown that the degree of porosity, order, and surface area of $l s m-\mathrm{TiO}_{2}$ catalyst can be controlled by tuning the titanium precursor/surfactant ratio. Moreover, the addition of acetylacetone chelating agent during the self-assembly process controlled the hydrolysis and condensation of $\mathrm{TiO}_{2}$ precursor and produced the desired phase of low-symmetry and hexagonal $\mathrm{TiO}_{2}\left(h m-\mathrm{TiO}_{2}\right)$ substrate [45-47]. In comparison to the highly hexagonal mesoporous structure, the $l s m-\mathrm{TiO}_{2}$ thin films have shown a significant enhancement of the OER activity in alkaline water because of the presence of short-range order, bimodal hierarchical pores, and transverse worm-like channels, which provided fast ions diffusion and interfacial electrons transport during the electrocatalytic process [36]. Furthermore, research on $\mathrm{TiO}_{2}$-based nanomaterials as bifunctional OER/ORR electrocatalysts has rarely been reported, and the synthesis of low-cost $\mathrm{TiO}_{2}$ hybrid bifunctional electrocatalysts is desired. This work reports a one-pot surfactant template approach to fabricate low-symmetry (disordered) mesoporous $\mathrm{TiO}_{2}$ substrates that modified with cobalt oxide nanoparticles to form $\mathrm{Co}_{3} \mathrm{O}_{4}(x) / l s m-\mathrm{TiO}_{2}$ hybrids. The physicochemical properties of surface morphology, crystal structure mesoporosity, and specific surface area of the produced catalysts and their corresponding electrocatalytic activities for the oxygen evolution and reduction reactions were examined. The $\mathrm{Co}_{3} \mathrm{O}_{4}(x) / l s m \mathrm{TiO}_{2}$ mesoporous catalyst exhibits enhanced performance as a bifunctional electrocatalyst toward the OER and the ORR in alkaline solution in comparison to the cobalt-doped 
hexagonal mesoporous $\mathrm{TiO}_{2}\left(\mathrm{Co}_{3} \mathrm{O}_{4} / h m-\mathrm{TiO}_{2}\right), \mathrm{Co}_{3} \mathrm{O}_{4} / b u l k-\mathrm{TiO}_{2}$, and also the commercially available $\mathrm{Pt} / \mathrm{C}$ and $\mathrm{IrO}_{2}$.

\section{Results and Discussion}

\subsection{Morphological and Physicochemical Characterization of the Cobalt Oxide-Modified Mesoporous $\mathrm{TiO}_{2}$}

Figure 1 shows the field emission scanning and transmission electron microscope (FESEM and TEM) images of the low-symmetry mesoporous $\mathrm{TiO}_{2}$ modified with cobalt oxide $\left(\mathrm{Co}_{3} \mathrm{O}_{4}(3) / l s m\right.$ - $\mathrm{TiO}_{2}$ and $\left.\mathrm{Co}_{3} \mathrm{O}_{4}(3) / \mathrm{hm}-\mathrm{TiO}_{2}\right)$. As shown in Figure $1 \mathrm{a}$, the $\mathrm{Co}_{3} \mathrm{O}_{4}(3) / \mathrm{lsm}$ - $\mathrm{TiO}_{2}$ catalyst exhibits a low-symmetry mesoporous structure with worm-like channels running throughout, and the pores tend to be well packed at short range. The FESEM image in Figure $1 \mathrm{~b}$ shows the typical surface morphology of mesoporous $\mathrm{Co}_{3} \mathrm{O}_{4}(3) / h m-\mathrm{TiO}_{2}$ with uniform and highly ordered two-dimensional (2D) hexagonal channels extended over a large domain. Figure 1c,d shows the representative TEM image of $\mathrm{Co}_{3} \mathrm{O}_{4}(3) / l \mathrm{sm}-\mathrm{TiO}_{2}$ and $\mathrm{Co}_{3} \mathrm{O}_{4}(3) / h m-\mathrm{TiO}_{2}$ catalysts, respectively. The TEM image in Figure $1 \mathrm{c}$ clearly demonstrates that the low-symmetry mesoporous structure of $\mathrm{Co}_{3} \mathrm{O}_{4}(3) / l \mathrm{sm}-\mathrm{TiO}_{2}$ contains large (primary) mesopores, connected by smaller pores (hierarchical porous structure) with a disordered pore arrangement. However, it is difficult to distinguish the cobalt nanoparticles from the $\mathrm{TiO}_{2}$ substrate. On the other hand, the TEM image in Figure 1d clearly shows the highly ordered cylindrical mesoporous channels of $\mathrm{TiO}_{2}$, with a pore size and a wall thickness of about 2.6 and $2.1 \mathrm{~nm}$, respectively. The cobalt oxide nanoparticles can be distinguished as dark spots that are uniformly distributed throughout the mesoporous hexagonal $\mathrm{TiO}_{2}$ substrate, as shown by the red circle in Figure $1 \mathrm{~d}$. Figure $1 \mathrm{f}$ shows the high-resolution TEM image of $\mathrm{Co}_{3} \mathrm{O}_{4}(3) / h m$ - $\mathrm{TiO}_{2}$ catalyst, which demonstrates that $\mathrm{Co}_{3} \mathrm{O}_{4}(3) / h m-\mathrm{TiO}_{2}$ has a crystalline nature with a lattice fringe spacing estimated at $0.345 \mathrm{~nm}$ index for $\mathrm{TiO}_{2}(101)$ diffraction plane. Moreover, the crystal lattice spacing of the cobalt oxide nanoparticles is estimated at 0.243 and $0.288 \mathrm{~nm}$, corresponding to the $\mathrm{Co}_{3} \mathrm{O}_{4}$ diffraction planes of (311) and (220), respectively. Upon increasing the cobalt content to $7.0 \mathrm{wt} . \%$, the nanoparticles aggregated to form larger assemblies, and a disordered $\mathrm{TiO}_{2}$ substrate was obtained, as shown in the TEM images of $\mathrm{Co}_{3} \mathrm{O}_{4}(7) / l s m-\mathrm{TiO}_{2}$ catalyst in Figure S1 (Supplementary Materials).

The crystalline phases of $l s m-\mathrm{TiO}_{2}$ and $\mathrm{Co}_{3} \mathrm{O}_{4}(x) / l s m-\mathrm{TiO}_{2}$ catalysts were examined using X-ray diffraction (XRD), as shown in Figure 2. Furthermore, the $\mathrm{XRD}$ curve of $\mathrm{Co}_{3} \mathrm{O}_{4}(3) / l \mathrm{sm}-\mathrm{TiO}_{2}$ catalyst was compared with those of $\mathrm{Co}_{3} \mathrm{O}_{4}(3) / b u l k-\mathrm{TiO}_{2}$ and $\mathrm{Co}_{3} \mathrm{O}_{4}(3) / h m-\mathrm{TiO}_{2}$ catalysts, as shown in Figure S2. As presented in Figure 2, the XRD patterns clearly show a series of diffraction peaks of a typical pure $\mathrm{TiO}_{2}$ anatase phase (JCPDS card No. 01-070-6826). Clearly, no characteristic diffraction peaks of CoO or $\mathrm{Co}_{3} \mathrm{O}_{4}$ are detected when the cobalt content is lower than $7.0 \mathrm{wt}$.\%. From the XRD patterns, it can be concluded that the incorporation of cobalt oxide seems not affected the anatase phase of $\mathrm{TiO}_{2}$ substrate, which is consistent with the TEM results. However, the existence of cobalt oxide diffraction peaks are observed for $\mathrm{Co}_{3} \mathrm{O}_{4}(7) / l s m-\mathrm{TiO}_{2}$ and $\mathrm{Co}_{3} \mathrm{O}_{4}(3) / b u l k-\mathrm{TiO}_{2}$, as shown in Figure 2 and Figure $\mathrm{S} 2$ (Supplementary Materials). The cobalt oxide diffraction peaks are centered at $2 \theta \sim 36.90$ and 38.8, which can be assigned to the (311) and (222) diffraction planes, respectively, of the cubic $\mathrm{Co}_{3} \mathrm{O}_{4}$ phase (JCPDS Card 00-042-1467). 

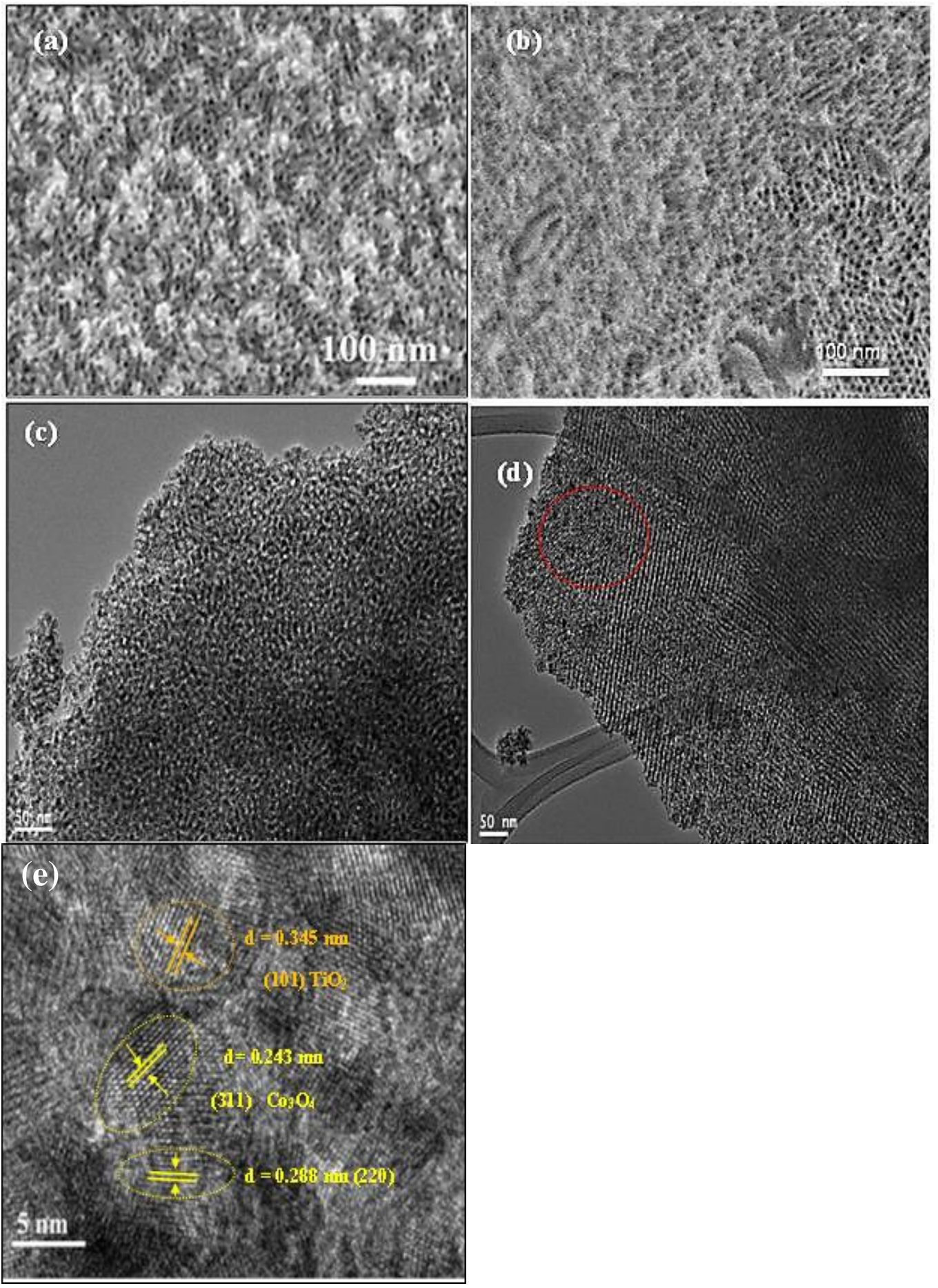

Figure 1. SEM images of (a) $\mathrm{Co}_{3} \mathrm{O}_{4}(3) / l s m-\mathrm{TiO}_{2}$ and (b) $\mathrm{Co}_{3} \mathrm{O}_{4}(3) / h m-\mathrm{TiO}_{2}$; typical TEM images of (c) $\mathrm{Co}_{3} \mathrm{O}_{4}(3) / l s m-\mathrm{TiO}_{2}$, (d) $\mathrm{Co}_{3} \mathrm{O}_{4}(3) / h m-\mathrm{TiO}_{2}$, and (e) high resolution TEM of $\mathrm{Co}_{3} \mathrm{O}_{4}(3) / h m-\mathrm{TiO}_{2}$ hybrid.

Figure $\mathrm{S} 3$ shows the effect of varying cobalt content on the average crystallite size of the $l s m-\mathrm{TiO}_{2}$ catalysts, as assessed from the half-height width of the main diffraction peak $\left(2 \theta=25.5^{\circ}\right)$ using Scherrer's equation. The curve in Figure $\mathrm{S} 3$ shows that the $\mathrm{TiO}_{2}$ crystal size increases significantly when the cobalt content exceeds $1.0 \mathrm{wt} . \%$ and, in general, the crystallite size of the $\mathrm{TiO}_{2}$ substrate is in the range between 5.93 and $6.8 \mathrm{~nm}$ for $\mathrm{Co}_{3} \mathrm{O}_{4}(x) / l s m-\mathrm{TiO}_{2}$, and $13.6 \mathrm{~nm}$ for $\mathrm{Co}_{3} \mathrm{O}_{4}(3) / b u l k-\mathrm{TiO}_{2}$. Our results demonstrate the key role of P123 surfactant, which acts as a capping agent around the 
nanoparticles, thereby stabilizing the porosity of the anatase phase of $\mathrm{TiO}_{2}$ during the sol-gel process in solution and the annealing process at higher temperature [35].

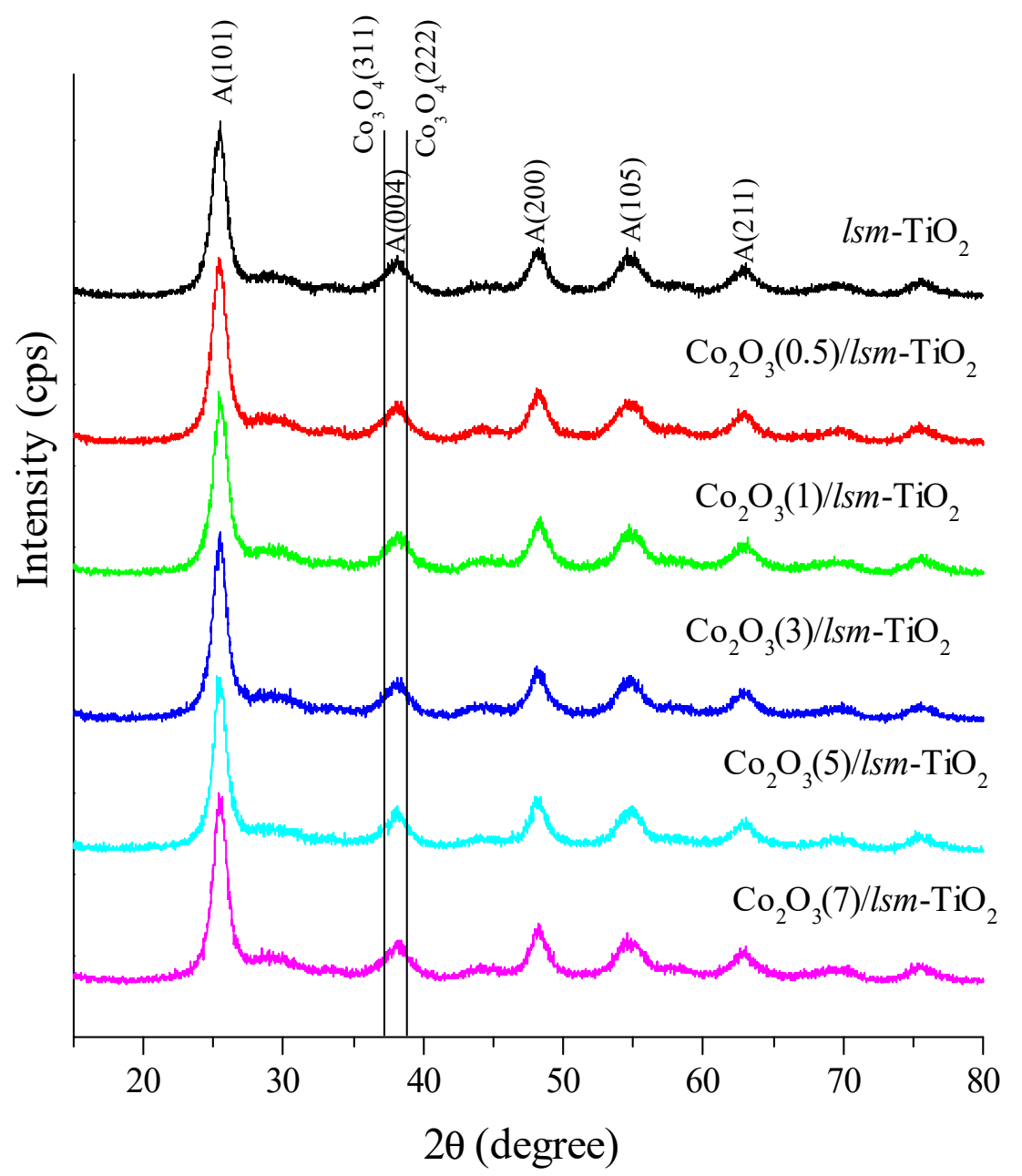

Figure 2. XRD patterns of $l s m-\mathrm{TiO}_{2}$ hybrids modified with different amount of cobalt oxide nanoparticles.

The X-Ray Photoelectron Spectroscopy (XPS) analysis was carried out to define the surface bonding of mesoporous $\mathrm{TiO}_{2}$ induced by cobalt dopant. Figure 3 displays the XPS survey spectra of pristine $l s m-\mathrm{TiO}_{2}$ and $\mathrm{Co}_{3} \mathrm{O}_{4}(3) / l s m-\mathrm{TiO}_{2}$ catalysts. Both spectra are very similar, except for the presence of the $\mathrm{Co} 2 \mathrm{p}_{3 / 2}$ peak at $780.4 \mathrm{eV}$. In addition to the $\mathrm{Ti}, \mathrm{O}$, and $\mathrm{Co} 2 \mathrm{p}_{3 / 2}$ peaks for $\mathrm{TiO}_{2}$ and $\mathrm{Co}_{3} \mathrm{O}_{4}(3) / l s m-\mathrm{TiO}_{2}$, carbon $\mathrm{C} 1 \mathrm{~s}$ signals are also observed in both samples. These could originate from the burnt surfactant or from carbon contamination during sample preparation and successive handling. Figure $3 \mathrm{~b}$ shows the high-resolution XPS spectra of Ti $2 \mathrm{p}$ of the pristine $l s m-\mathrm{TiO}_{2}$ and $\mathrm{Co}_{3} \mathrm{O}_{4}(3) / l s m-\mathrm{TiO}_{2}$ catalysts. The Ti $2 \mathrm{p}_{3 / 2}$ and $\mathrm{Ti} 2 \mathrm{p}_{1 / 2}$ spectrum peaks of pristine $l s m-\mathrm{TiO}_{2}$ are identical to their binding energy (BE) at 459.55 and $465.29 \mathrm{eV}$, respectively, implying the $\mathrm{Ti}^{4+}$ state [48]. The spin-orbit splitting energy of those two peaks is $5.74 \mathrm{eV}$, which is identical to that reported in the literature [49]. 

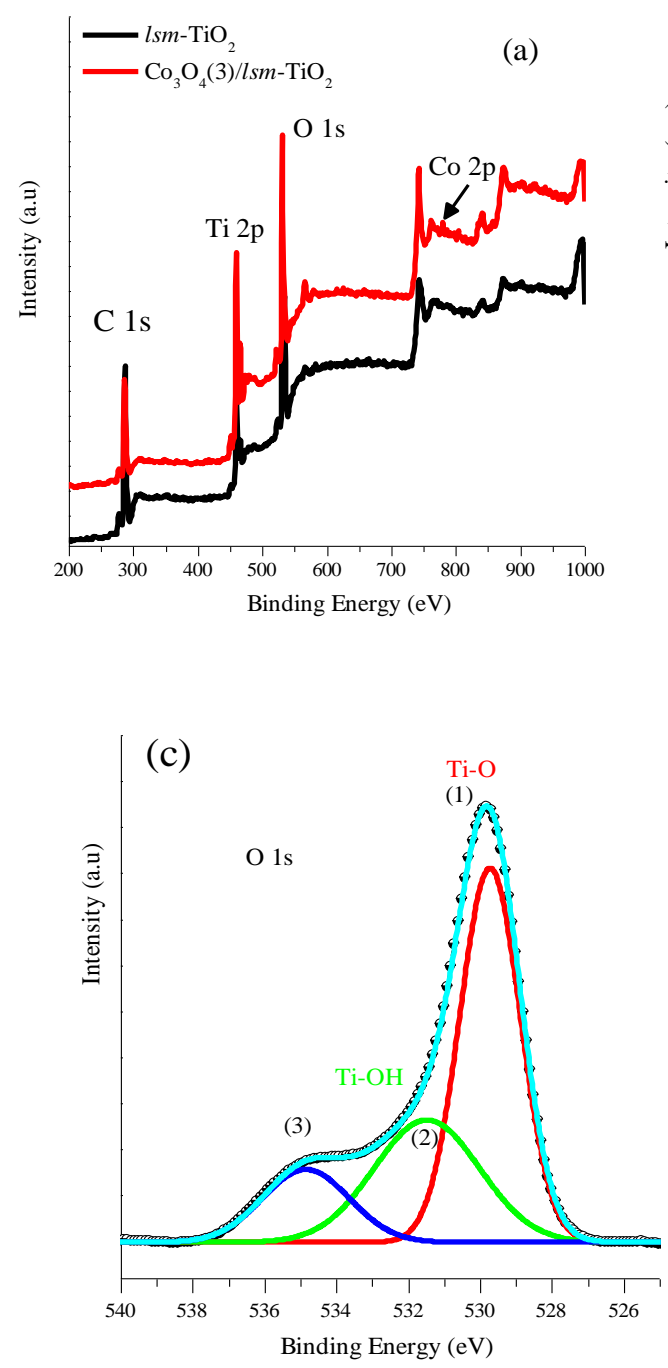
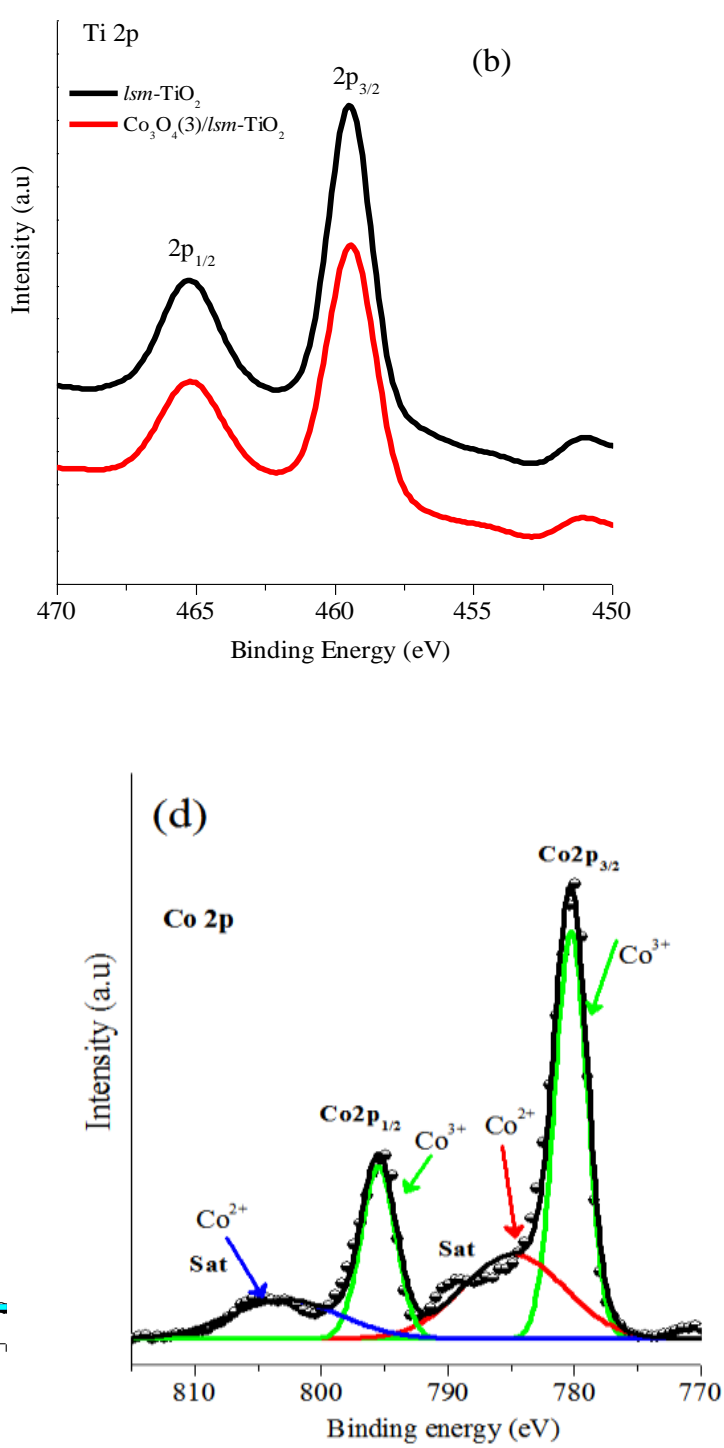

Figure 3. (a) The XPS survey spectra of pristine $l s m-\mathrm{TiO}_{2}$ and $\mathrm{Co}_{3} \mathrm{O}_{4}(3) / l s m-\mathrm{TiO}_{2}$ hybrids, (b) core spectra of $\mathrm{Ti} 2 \mathrm{p}$ for $l s m-\mathrm{TiO}_{2}$ and $\mathrm{Co}_{3} \mathrm{O}_{4}(3) / l s m-\mathrm{TiO}_{2}$ catalysts, (c) $\mathrm{O} 1 \mathrm{~s}$ of $\mathrm{Co}_{3} \mathrm{O}_{4}(3) / l s m-\mathrm{TiO}_{2}$ catalyst, and (d) Co 2 p core-levels.

In the presence of cobalt dopant, the $\mathrm{Ti} 2 \mathrm{P}_{3 / 2}$ peaks of $l s m-\mathrm{TiO}_{2}$ and $\mathrm{Co}_{3} \mathrm{O}_{4}(3) / l s m-\mathrm{TiO}_{2}$ catalysts are almost identical to that of the pure one, except for a slight red-shift in the $\mathrm{BE}$ of $0.15 \mathrm{eV}$, which is consistent with previous reports [50-52]. Figure $3 \mathrm{c}$ displays the XPS spectra of the $\mathrm{O} 1 \mathrm{~s}$ of $\mathrm{Co}_{3} \mathrm{O}_{4}(3) / \mathrm{lsm}-\mathrm{TiO}_{2}$, and three Gaussian peaks assigned as (1), (2), and (3) were used to fit the experimental data. The peak positioned at $529.83 \mathrm{eV}$ belongs to the $\mathrm{Ti}-\mathrm{O}$ bond in $\mathrm{TiO}_{2}$. The peak located at $531.6 \mathrm{eV}$ can be ascribed to the Ti-OH bond, which was reported to be positioned at a $\mathrm{BE} \sim 1.5-1.8 \mathrm{eV}$ higher than the $\mathrm{O} 1 \mathrm{~s}$ of $\mathrm{TiO}_{2}[53,54]$. These results prove that the introduction of $\mathrm{Co}$ dopants in $\mathrm{Co}_{3} \mathrm{O}_{4}(3) / l \mathrm{sm}-\mathrm{TiO}_{2}$ creates an enriched quantity of surface $\mathrm{O}$ vacancies in the form of metal-OH bonds. The chemical structure and oxidation states of Co dopants in $l s m$ - $\mathrm{TiO}_{2}$ hybrids were well demonstrated in the XPS analysis (Figure 3d). The Co $2 \mathrm{p}$ spectra exhibit two main peaks with binding energies of $781.3 \mathrm{eV}$ (Co 2 $\mathrm{p}_{3 / 2}$ ) and $796.9 \mathrm{eV}\left(\mathrm{Co} 2 \mathrm{p}_{1 / 2}\right)$, accompanied by two strong shakeup satellite peaks toward higher binding energies posited at nearly $6 \mathrm{eV}$ from the main peaks, which suggests $\mathrm{Co}_{3} \mathrm{O}_{4}$ phase with two valence states (octahedral $\mathrm{Co}^{3+}$ and tetrahedral $\mathrm{Co}^{2+}$ ) coexist in $\mathrm{Co} / \mathrm{lsm}-\mathrm{TiO}_{2}$ [55]. After deconvolution of $\mathrm{Co} 2 \mathrm{p}$ spectra, the energy difference between the Co $2 \mathrm{p}_{3 / 2}$ and the Co $2 \mathrm{p}_{1 / 2}$ peak had a separation of $\sim 15.1 \mathrm{eV}$, which further indicates that the oxidation state of cobalt in the $l s m-\mathrm{TiO}_{2}$ lattice is mixed-valence $\mathrm{Co}_{3} \mathrm{O}_{4}$. 
The elemental composition analysis of XPS spectra in Figure 3a indicates a $2.92 \mathrm{wt} . \%$ cobalt content for the $\mathrm{Co}_{3} \mathrm{O}_{4}(3) / l s m-\mathrm{TiO}_{2}$ catalyst, as shown in Table S1. In addition, Figures $\mathrm{S} 4$ and $\mathrm{S} 5$ show the Scanning electron microscope- Energy dispersive X-ray SEM-EDX elements mapping of $\mathrm{Co}_{3} \mathrm{O}_{4}(3) / l s m-\mathrm{TiO}_{2}$ and $\mathrm{Co}_{3} \mathrm{O}_{4}(3) / h m-\mathrm{TiO}_{2}$ catalysts, respectively. Clearly, the images of EDX elements mapping demonstrate the uniform distribution of $\mathrm{Co}_{3} \mathrm{O}_{4}$ within both the low-symmetry and hexagonal $\mathrm{TiO}_{2}$ substrate. The EDX analysis reveals that the cobalt content is very close for both low-symmetry and hexagonal $\mathrm{TiO}_{2}$ substrate and reaches $3.7 \%$ and $3.83 \%$, respectively.

The mesoporosity of the obtained $l s m-\mathrm{TiO}_{2}, \mathrm{Co}_{3} \mathrm{O}_{4}(x) / l s m-\mathrm{TiO}_{2}$, and $\mathrm{Co}_{3} \mathrm{O}_{4}(3) / \mathrm{hm}-\mathrm{TiO}_{2}$ samples are characterized by the $\mathrm{N}_{2}$-physisorption technique, and the results are shown in Figure 4 . The $\mathrm{N}_{2}$ sorption isotherms of the produced catalysts in Figure 4a exhibit characteristic type IV curves and H1 hysteresis loops with capillary condensation steps, which are distinctive of mesoporous materials according to the IUPAC classification [56,57]. Figure 4a demonstrates distinct capillary condensation at $\mathrm{P} / \mathrm{P}_{0}=0.4-0.7$, indicating the uniform and narrow mesopore size distribution, which is consistent with the TEM results. The pore size distribution of the $l s m-\mathrm{TiO}_{2}$ and $\mathrm{Co}_{3} \mathrm{O}_{4}(x) / l s m-\mathrm{TiO}_{2}$ samples were assessed from the adsorption data via the $\mathrm{BJH}$ method, and is shown in Figure $4 \mathrm{~b}$.
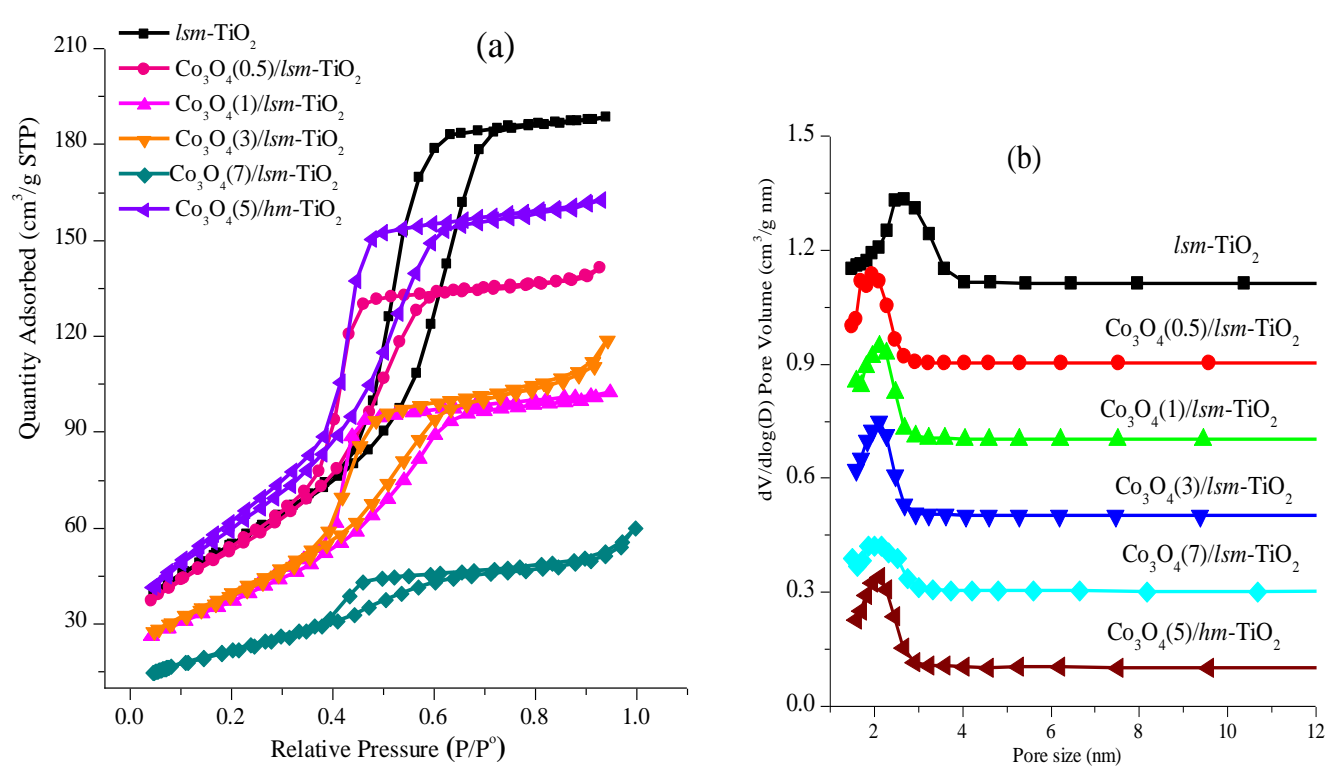

Figure 4. (a) The $\mathrm{N}_{2}$ sorption isotherms and (b) corresponding pore size distribution of the $l s m-\mathrm{TiO}_{2}$ modified with different loadings of cobalt oxide nanoparticles.

The pore size analysis shows that as the cobalt content increases, the pore size distribution becomes wider in the case of $\mathrm{Co}_{3} \mathrm{O}_{4}(7) / / \mathrm{sm}-\mathrm{TiO}_{2}$. This is probably due to the structural damage from the growth of cobalt oxide nanoparticles. The specific texture parameters of the samples are presented in Table 1. We can observe that the specific surface area (SSA) and the pore volumes of low symmetry mesoporous $\mathrm{TiO}_{2}$ substrate tend to decline as the cobalt content increases due to the deteriorating mesoporous structure, which is consistent with the above TEM and XRD results. 
Table 1. Textural properties of the $l s m-\mathrm{TiO}_{2}$ and $\mathrm{Co}_{3} \mathrm{O}_{4}(x) / l s m-\mathrm{TiO}_{2}$ catalyst derived from nitrogen adsorption and desorption data.

\begin{tabular}{cccc}
\hline Catalyst & BET Surface Area $\left(\mathbf{m}^{\mathbf{2}} \mathbf{g}^{-\mathbf{1}}\right)^{\mathbf{a}}$ & Pore Size $(\mathbf{n m})$ & Pore Volume $\mathbf{( c m}^{\mathbf{3}} \mathbf{g}^{\mathbf{- 1}} \mathbf{~}^{\mathbf{c}}$ \\
\hline$l s m-\mathrm{TiO}_{2}$ & 200 & 2.7 & 0.290 \\
$\mathrm{Co}_{3} \mathrm{O}_{4}(0.5) / l s m-\mathrm{TiO}_{2}$ & 175 & 2.01 & 0.25 \\
$\mathrm{Co}_{3} \mathrm{O}_{4}(1) / l s m-\mathrm{TiO}_{2}$ & 158 & 2.03 & 0.17 \\
$\mathrm{Co}_{3} \mathrm{O}_{4}(3) / l s m-\mathrm{TiO}_{2}$ & 146 & 2.11 & 0.11 \\
$\mathrm{Co}_{3} \mathrm{O}_{4}(5) / l s m-\mathrm{TiO}_{2}$ & 119 & 1.95 & 0.10 \\
$\mathrm{Co}_{3} \mathrm{O}_{4}(7) / l s m-\mathrm{TiO}_{2}$ & 81 & 1.83 & 0.071 \\
$\mathrm{Co}_{3} \mathrm{O}_{4}(3) / h m-\mathrm{TiO}_{2}$ & 229 & 2.11 & 0.22 \\
$\mathrm{Co}_{3} \mathrm{O}_{4}(3) / b u l k-\mathrm{TiO}_{2}$ & 42 & 1.50 & 0.025 \\
\hline
\end{tabular}

a $\mathrm{BET}$ is evaluated by the BET equation; ${ }^{\mathrm{b}}$ Pore size is determined by the $\mathrm{BJH}$ method; ${ }^{\mathrm{c}}$ Total pore volume is calculated at $\mathrm{p} / \mathrm{p}_{0}=0.950-0.995$.

\subsection{Electrochemical Performance of the Mesoporous $\mathrm{TiO}_{2}$ Modified with Cobalt Oxide Nanoparticles for OER}

Figure 5a shows the linear sweep voltammetry (LSV) curve of $\mathrm{Co}_{3} \mathrm{O}_{4}(x) / l s m-\mathrm{TiO}_{2}$ catalyst at $10 \mathrm{mV} \mathrm{s}^{-1}$ in $1.0 \mathrm{M}$ of $\mathrm{KOH}$ solution in a conventional 3-electrode cell. For comparison purposes, Figure $5 \mathrm{~b}$ shows the $\mathrm{LSV}$ curve of $l s m-\mathrm{TiO}_{2}, \mathrm{Co}_{3} \mathrm{O}_{4}(3) / h m-\mathrm{TiO}_{2}, \mathrm{Co}_{3} \mathrm{O}_{4}(3) / b u l k-\mathrm{TiO}_{2}$, and commercial $\mathrm{IrO}_{2}$ catalysts recorded under similar conditions. Based on the LSV results, the $\mathrm{TiO}_{2}$-base catalysts exhibit a certain degree of OER electrochemical activity in alkaline solution. The bare CP does not show any catalytic activity for the OER, while the pure $l s m-\mathrm{TiO}_{2}$ catalyst exhibits an OER overpotential of $490 \mathrm{mV}$ at a current density of $10 \mathrm{~mA} \mathrm{~cm}^{-2}$. With the incorporation of cobalt oxide nanoparticles, the OER activity is significantly improved, as evidenced by the onset potential of $1.48 \mathrm{~V}$ vs. RHE and the overpotential $(\eta)$ of $348 \mathrm{mV}$ at $10 \mathrm{~mA} \mathrm{~cm}^{-2}$ in the case of $\mathrm{Co}_{3} \mathrm{O}_{4}(3) / l \mathrm{sm}-\mathrm{TiO}_{2}$. This overpotential is $142 \mathrm{mV}$ lower than that of the corresponding pure $l s m-\mathrm{TiO}_{2}$. The mesoporous $\mathrm{Co}_{3} \mathrm{O}_{4}(3) / l s m-\mathrm{TiO}_{2}$ catalyst shows superior performance in comparison to $\mathrm{Co}_{3} \mathrm{O}_{4}(3) / \mathrm{hm}-\mathrm{TiO}_{2}(452 \mathrm{mV})$ and $\mathrm{Co}_{3} \mathrm{O}_{4}(3) / b u l k-\mathrm{TiO}_{2}(470 \mathrm{mV})$ that are prepared by the same procedure, and even with respect to commercial $\mathrm{IrO}_{2}$ catalyst $(354 \mathrm{mV})$ at the same current density of $10 \mathrm{~mA} \mathrm{~cm}^{-2}$, as shown in Table 2 and Figure $5 \mathrm{~b}$. The OER kinetics was further investigated using a Tafel plot by fitting the LSV data to the equation: $\eta=\mathrm{b} \log j+\mathrm{a}$, where $j$ and $\mathrm{b}$ are the current density and Tafel slope, respectively [51]. As shown in Figure $5 \mathrm{c}$ and Table 2, the $\mathrm{Co}_{3} \mathrm{O}_{4}(3) / l \mathrm{sm}$ - $\mathrm{TiO}_{2}$ catalyst has the smallest Tafel slope (54 $\left.\mathrm{mV} \mathrm{dec}^{-1}\right)$, making it the most efficient one among the investigated and reference catalysts. For further evaluation of the electrocatalytic behavior of the cobalt oxide-modified mesoporous $\mathrm{TiO}_{2}$ hybrids for the OER, the mass activity and turnover frequency (TOF) were calculated at an overpotential of $\eta=0.370 \mathrm{~V}(1.6 \mathrm{~V}$ vs. RHE), and are reported in Table 2. The TOF and mass activity of our electrocatalysts were calculated according to the method reported by Gao et al. [58], shown in the Supplementary Materials. The mass activity of $\mathrm{Co}_{3} \mathrm{O}_{4}(3) / l s m-\mathrm{TiO}_{2}$ at a potential $1.6 \mathrm{~V}$ vs. RHE reaches $42 \mathrm{~A} \mathrm{~g}^{-1}$, and the TOF value equals $0.035 \mathrm{~s}^{-1}$ at $\eta=370 \mathrm{mV}$. Clearly, the mass activity and TOF values of $\mathrm{Co}_{3} \mathrm{O}_{4}(3) / l \mathrm{sm}-\mathrm{TiO}_{2}$ are superior to those of the other investigated electrocatalysts and comparable to those recently reported for the state-of-the-art catalysts [59-62]. From the data in Table 2, the TOF value of $\mathrm{Co}_{3} \mathrm{O}_{4}(3) / l s m-\mathrm{TiO}_{2}$ catalyst is about $\sim 12.5, \sim 17.5$, and $\sim 1.85$ orders of magnitude higher than that of the $\mathrm{Co}_{3} \mathrm{O}_{4}(3) / h m-\mathrm{TiO}_{2}(0.0028)$, $\mathrm{Co}_{3} \mathrm{O}_{4}(3) / b u l k-\mathrm{TiO}_{2}(0.002)$, and $\mathrm{IrO}_{2}(0.019)$ catalysts, respectively. The superior OER activity of $\mathrm{Co}_{3} \mathrm{O}_{4}(3) / l s m-\mathrm{TiO}_{2}$ could be attributed to the synergistic effect of $\mathrm{Co}_{3} \mathrm{O}_{4}(3) / \mathrm{TiO}_{2}$, as well as that the low-symmetry $\mathrm{TiO}_{2}$ substrate provide a short diffusion path for ions mass transport, which is better than the hexagonal ordered continuous channels.

Figure $5 \mathrm{~d}$ shows the LSV curve of the $\mathrm{Co}_{3} \mathrm{O}_{4}(3) / l s m-\mathrm{TiO}_{2}$ electrode tested under various $\mathrm{KOH}$ concentrations $(0.1,1.0 \mathrm{M}$ ) and extremely alkaline conditions (such as concentrated $5.0 \mathrm{M}$ of $\mathrm{KOH}$ solution), which are often encountered in commercial alkaline water electrolysis [63]. As shown in Figure $5 \mathrm{~d}$ and Table 3, the OER performances of the $\mathrm{Co}_{3} \mathrm{O}_{4}(3) / \mathrm{lsm}$ - $\mathrm{TiO}_{2}$ catalyst in $0.1,1.0$, and $5.0 \mathrm{M}$ $\mathrm{KOH}$ display an onset potential of 317,227 , and $160 \mathrm{mV}$ vs. SCE, respectively, and a current density of $20 \mathrm{~mA} \mathrm{~cm}^{-2}$ was obtained in $5.0 \mathrm{M} \mathrm{KOH}$ at an overpotential of $272 \mathrm{mV}$, which is 240 and $65 \mathrm{mV}$ lower than that acquired in 0.1 and $1 \mathrm{M} \mathrm{KOH}$, respectively. 

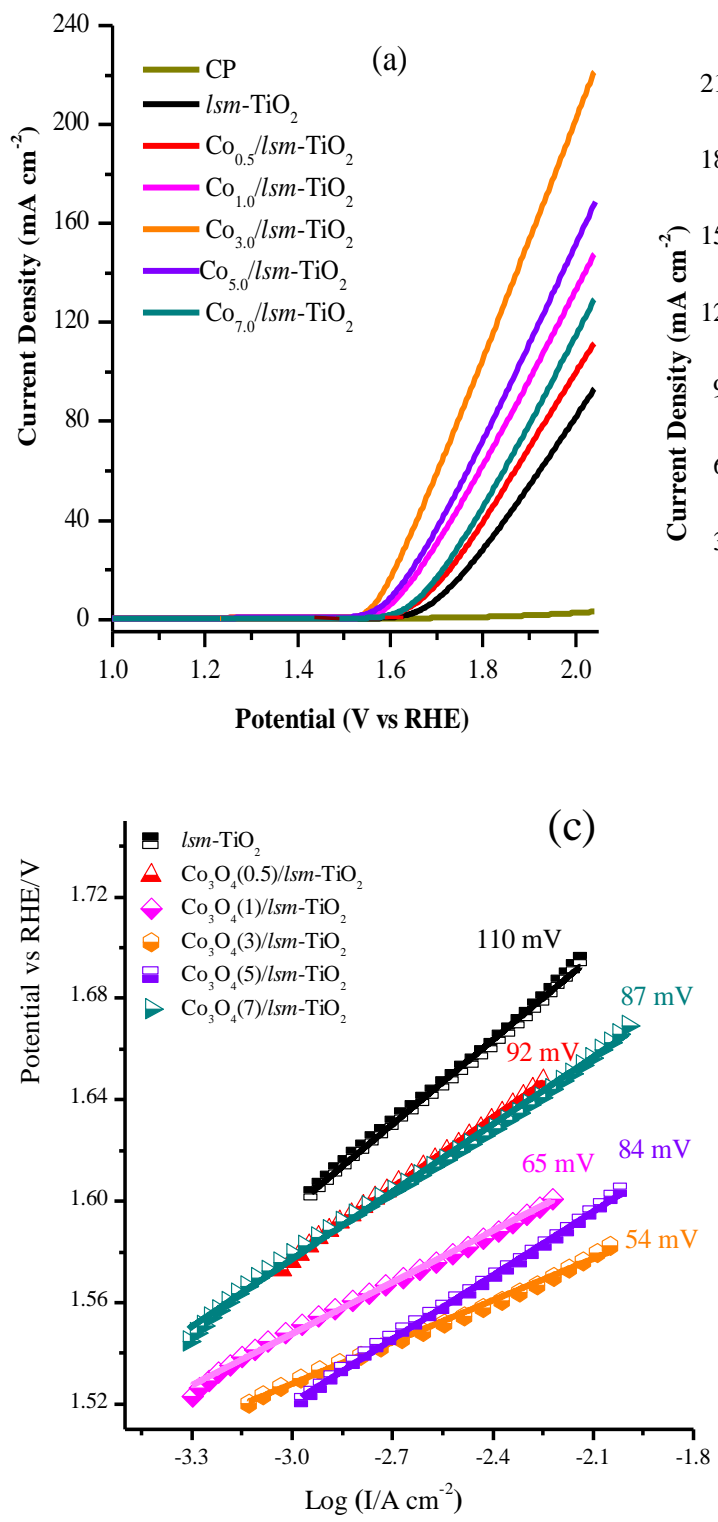
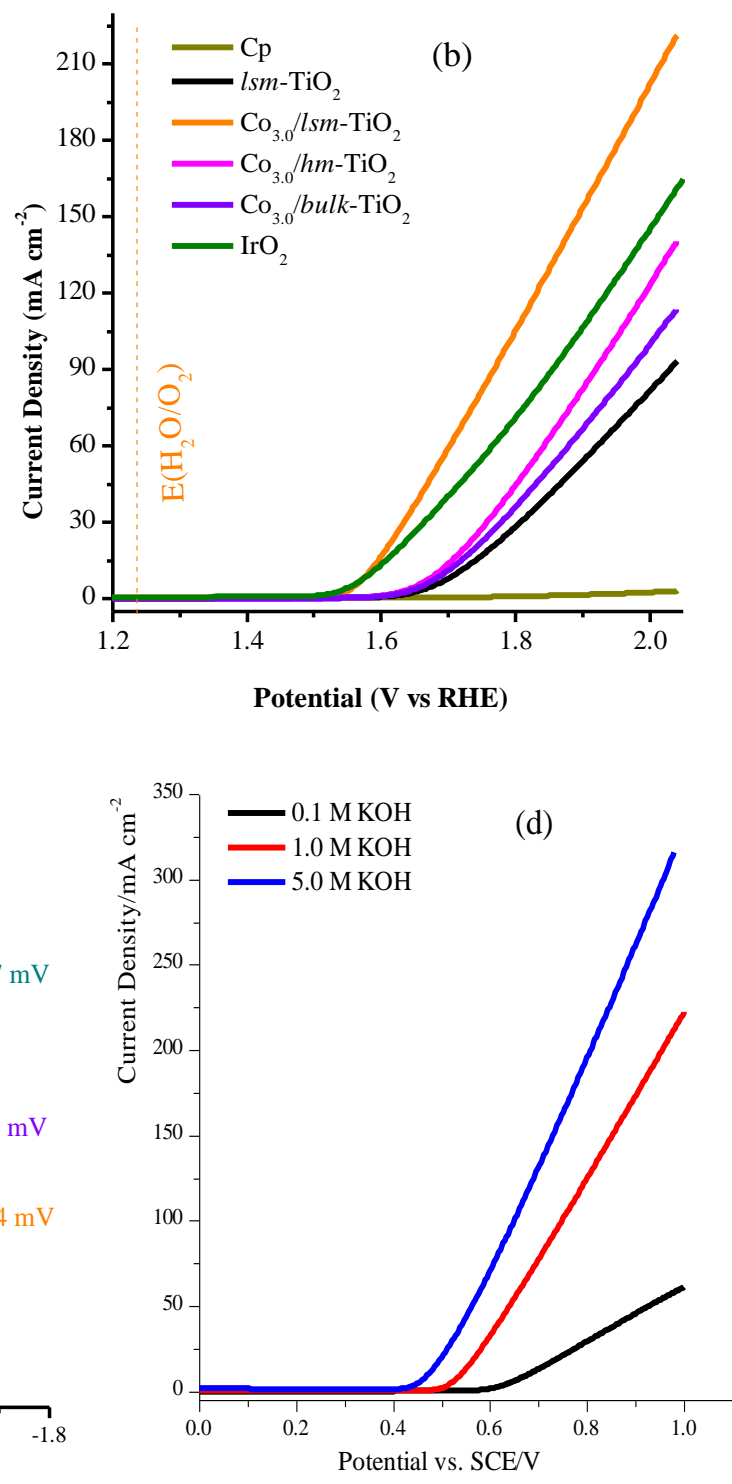

Figure 5. (a) The anodic-going sweep of LSV at $10 \mathrm{mV} \mathrm{s}^{-1}$ for a bare $\mathrm{CP}$, and the $\mathrm{Co}_{3} \mathrm{O}_{4}(x) / l s m-\mathrm{TiO}_{2}$ hybrids in $1.0 \mathrm{M}$ of $\mathrm{KOH}$ solution (catalyst loading $\sim 0.8 \mathrm{mg} / \mathrm{cm}^{2}$ for all the electrodes); (b) LSV curves of $l s m-\mathrm{TiO}_{2}, \mathrm{Co}_{3} \mathrm{O}_{4}(3) / l s m-\mathrm{TiO}_{2} \mathrm{Co}_{3} \mathrm{O}_{4}(3) / h m-\mathrm{TiO}_{2}, \mathrm{Co}_{3} \mathrm{O}_{4}(3) / b u l k-\mathrm{TiO}_{2}$, and commercial $\mathrm{IrO}_{2}$ recorded in $1.0 \mathrm{M}$ of $\mathrm{KOH}$ at $10 \mathrm{mV} \mathrm{s}^{-1}$; (c) Tafel curves of $\mathrm{Co}_{3} \mathrm{O}_{4}(x) / l \mathrm{sm}-\mathrm{TiO}_{2}$ as extracted from LSV in (a); and (d) $\mathrm{LSV}$ of $\mathrm{Co}_{3} \mathrm{O}_{4}(3) / l s m-\mathrm{TiO}_{2}$ electrode performed in various $\mathrm{KOH}$ concentrations of $0.1,1.0$, and $5.0 \mathrm{M}$.

Table 2. The electrochemical parameters of the mesoporous $\mathrm{TiO}_{2}$ modified with cobalt oxide nanoparticles, as obtained from the LSV in Figure 5.

\begin{tabular}{|c|c|c|c|c|c|c|c|}
\hline Catalysts & $\begin{array}{c}\text { Onset } \\
\text { Potential vs. } \\
\text { RHE/V a }\end{array}$ & $\begin{array}{c}\eta(\mathrm{mV}) \\
\text { at }\left(10 \mathrm{~mA} / \mathrm{cm}^{2}\right)^{b}\end{array}$ & $\begin{array}{c}\eta(\mathrm{mV}) \\
\text { at }\left(20 \mathrm{~mA} / \mathrm{cm}^{2}\right)^{c}\end{array}$ & $\begin{array}{c}\text { Current } \\
\mathrm{mA} / \mathrm{cm}^{2} \text { at } 2.0 \mathrm{~V} \\
\text { vs. RHE }\end{array}$ & $\begin{array}{l}\text { Tafel Slope } \\
\text { (mV/dec) }^{d}\end{array}$ & $\begin{array}{c}\text { mass Activity } \\
\text { at } 1.6 \mathrm{~V} \\
\left(\mathrm{~A} \mathrm{~g}^{-1}\right)^{\mathrm{e}}\end{array}$ & $\begin{array}{c}\text { TOF at } \\
\eta=0.370 \mathrm{~V}\left(\mathrm{~s}^{-1}\right)^{\mathrm{f}}\end{array}$ \\
\hline$l s m-\mathrm{TiO}_{2}$ & 1.620 & 490 & 530 & 94 & 98 & 2 & 0.00033 \\
\hline $\mathrm{Co}_{3} \mathrm{O}_{4}(0.5) / l s m-\mathrm{TiO}_{2}$ & 1.510 & 449 & 492 & 113 & 92 & 5 & 0.0038 \\
\hline $\mathrm{Co}_{3} \mathrm{O}_{4}(1) / \mathrm{lsm}-\mathrm{TiO}_{2}$ & 1.490 & 390 & 432 & 149 & 65 & 15 & 0.012 \\
\hline $\mathrm{Co}_{3} \mathrm{O}_{4}(3) / l s m-\mathrm{TiO}_{2}$ & 1.485 & 348 & 370 & 222 & 54 & 42 & 0.035 \\
\hline $\mathrm{Co}_{3} \mathrm{O}_{4}(5) / l s m-\mathrm{TiO}_{2}$ & 1.490 & 370 & 410 & 170 & 84 & 23 & 0.020 \\
\hline $\mathrm{Co}_{3} \mathrm{O}_{4}(7) / l s m-\mathrm{TiO}_{2}$ & 1.530 & 437 & 481 & 131 & 87 & 5 & 0.0037 \\
\hline $\mathrm{Co}_{3} \mathrm{O}_{4}(3) / h m-\mathrm{TiO}_{2}$ & 1.58 & 452 & 490 & 141 & 121 & 3 & 0.0028 \\
\hline $\mathrm{Co}_{3} \mathrm{O}_{4}(3) / b u l k-\mathrm{TiO}_{2}$ & 1.590 & 470 & 510 & 114 & 91 & 3 & 0.0020 \\
\hline $\mathrm{IrO}_{2}$ & 1.475 & 354 & 398 & 164 & 81 & 34 & 0.019 \\
\hline
\end{tabular}

${ }^{\mathrm{a}}$ Onset overpotential; ${ }^{\mathrm{b}}$ Overpotential at $\mathrm{j}=10,20 \mathrm{~mA} / \mathrm{cm}^{2} ;{ }^{\mathrm{d}}$ Tafel slope estimated from the Tafel equation: $\eta=\mathrm{b} \log$ $(\mathrm{j} / \mathrm{j0}){ }^{\mathrm{e}}$ The values of mass activity; ${ }^{\mathrm{d}}$ Turnover frequency (TOF), see Supporting Material for the calculation method. 
Table 3. Overpotential values calculated at 10 and $20 \mathrm{~mA} / \mathrm{cm}^{2}$, and current density at $1.0 \mathrm{~V}$ vs. SCE, of $\mathrm{Co}_{3} \mathrm{O}_{4}(3) / l s m-\mathrm{TiO}_{2}$ obtained in various $\mathrm{KOH}$ concentrations.

\begin{tabular}{|c|c|c|c|c|}
\hline $\begin{array}{c}\text { Electrolyte } \\
(\mathrm{KOH})\end{array}$ & $\begin{array}{c}\eta(\mathrm{mV}) \\
\text { at } 10 \mathrm{~mA} / \mathrm{cm}^{2}\end{array}$ & $\begin{array}{c}\eta(\mathrm{mV}) \\
\text { at } 20 \mathrm{~mA} / \mathrm{cm}^{2}\end{array}$ & $\begin{array}{c}\mathrm{I}\left(\mathrm{mA} / \mathrm{cm}^{2}\right) \text { at } \\
1.0 \mathrm{~V}\end{array}$ & $\begin{array}{c}\text { Tafel Slope } \\
\text { mV/dec }\end{array}$ \\
\hline $0.1 \mathrm{M}$ & 445 & 512 & 61 & 87 \\
\hline $1.0 \mathrm{M}$ & 309 & 337 & 222 & 54 \\
\hline $5.0 \mathrm{M}$ & 243 & 272 & 318 & 71 \\
\hline
\end{tabular}

The long-term stability of $\mathrm{Co}_{3} \mathrm{O}_{4}(3) / l s m-\mathrm{TiO}_{2}$ catalyst and the ability to continuously catalyze the OER were examined using continuous cycling and chronoamperometry (CA) in $1.0 \mathrm{M} \mathrm{KOH}$. Figure 6a displays the $\mathrm{LSV}$ curves of a $\mathrm{Co}_{3} \mathrm{O}_{4}(3) / / \mathrm{sm}$ - $\mathrm{TiO}_{2}$ electrode before and after 2500 cycles in $1.0 \mathrm{M} \mathrm{KOH}$ at $10 \mathrm{mV} \mathrm{s}^{-1}$. The catalyst clearly exhibits a similar LSV after extended cycling with negligible loss of the OER anodic current, confirming satisfactory durability in alkaline electrolytes. To further assess the superior durability of the $\mathrm{Co}_{3} \mathrm{O}_{4}(3) / l s m-\mathrm{TiO}_{2}$ catalyst, Figure $6 \mathrm{~b}$ shows the CA response of $\mathrm{Co}_{3} \mathrm{O}_{4}(3) / \mathrm{lsm}-\mathrm{TiO}_{2}$ and the benchmark $\mathrm{IrO}_{2}$ catalysts measured for $9 \mathrm{~h}$ at $1.65 \mathrm{~V}$ vs. RHE in $1.0 \mathrm{M} \mathrm{KOH}$. Figure $6 \mathrm{~b}$ demonstrates that the benchmark $\mathrm{IrO}_{2}$ electrocatalyst shows an anode current loss of $90 \%$ after continuous operation for $9 \mathrm{~h}$ in $1.0 \mathrm{M} \mathrm{KOH}$ solution. In contrast, the $\mathrm{Co}_{3} \mathrm{O}_{4}(3) / l s m-\mathrm{TiO}_{2}$ catalyst exhibits an oxygen evolution current over 13 times higher than that of $\mathrm{IrO}_{2}$, and offers a stable current with the negligible loss ( $8 \%$ ) after $9 \mathrm{~h}$ of electrolysis at the same potential, in agreement with the results of the incessant potential CV sweeps. These results suggest that $\mathrm{Co}_{3} \mathrm{O}_{4}(3) / l s m-\mathrm{TiO}_{2}$ is functioned as an effective electrocatalyst to drive water oxidation with great durability. The performance of $\mathrm{Co}_{3} \mathrm{O}_{4}(3) / l s m-\mathrm{TiO}_{2}$ is not only higher than those of $\mathrm{IrO}_{2}, \mathrm{Co}_{3} \mathrm{O}_{4}(3) / h m-\mathrm{TiO}_{2}$, and $\mathrm{Co}_{3} \mathrm{O}_{4}(3) / b u l k-\mathrm{TiO}_{2}$, but also higher than those of other reported state-of-the-art cobalt-based electrocatalysts [58-60]. A comprehensive assessment of alkaline OER performance and catalyst parameters is delivered in Table S2.
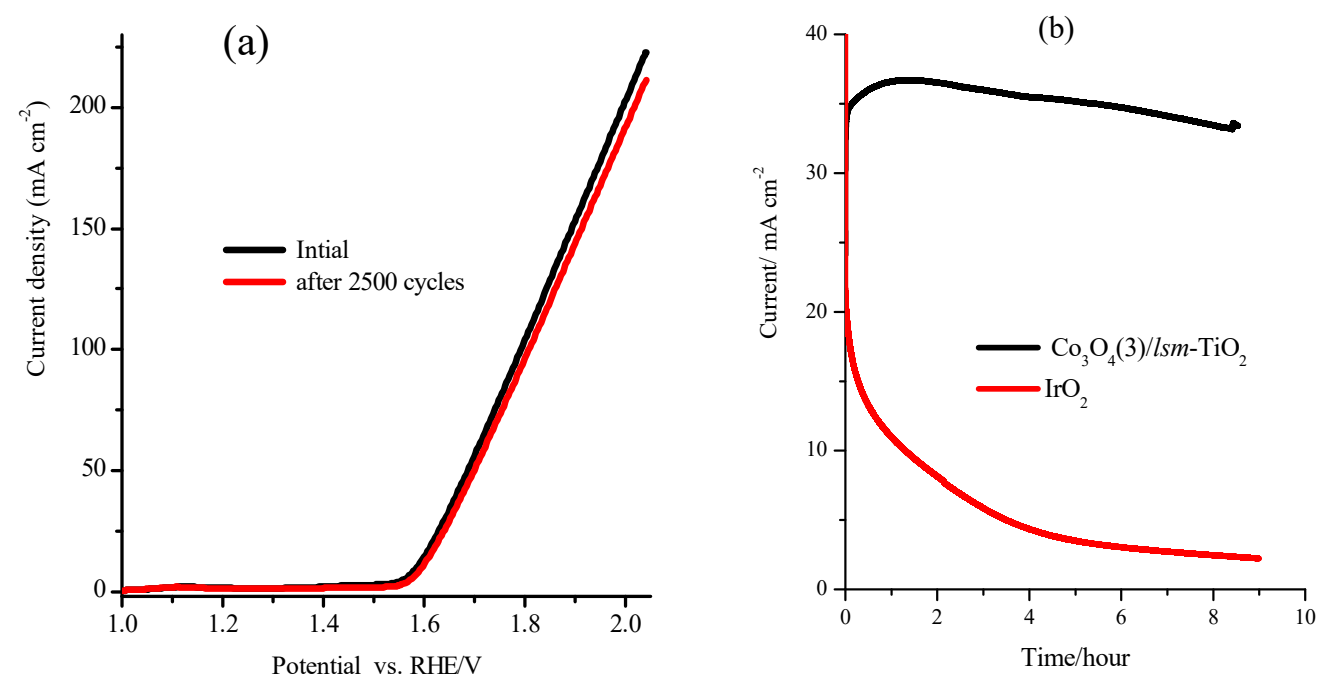

Figure 6. (a) LSV curves at $10 \mathrm{mV} \mathrm{s}^{-1}$ for the first and after 2500 cycles of $\mathrm{Co}_{3} \mathrm{O}_{4}(3) / l \mathrm{sm}-\mathrm{TiO}_{2}$ electrode in $1.0 \mathrm{M}$ of $\mathrm{KOH}$ solution; (b) the chronoamperometry of $\mathrm{Co}_{3} \mathrm{O}_{4}(3) / l s m-\mathrm{TiO}_{2}$ electrode and the benchmark $\mathrm{IrO}_{2}$ catalysts measured for $9 \mathrm{~h}$ at $1.65 \mathrm{~V}$ vs. RHE in $1.0 \mathrm{M} \mathrm{KOH}$.

Further the electrochemical impedance spectroscopy EIS analysis measurements were also performed to get further insight into the kinetics of electrode reactions before and after doping with cobalt oxide nanoparticles. Figure 7a presents typical Nyquist plots of the impedance data obtained for the pure $l s m-\mathrm{TiO}_{2}, \mathrm{Co}_{3} \mathrm{O}_{4}(3) / l s m-\mathrm{TiO}_{2}, \mathrm{Co}_{3} \mathrm{O}_{4}(3) / h m-\mathrm{TiO}_{2}$, and $\mathrm{Co}_{3} \mathrm{O}_{4}(3) / b u l k-\mathrm{TiO}_{2}$ electrodes at $1.6 \mathrm{~V}$ vs. RHE. The low-frequency area of the Nyquist plot ( $\mathrm{Z}^{\prime}$ vs. $\left.-\mathrm{Z}^{\prime \prime}\right)$ and the equivalent circuit, presented in the inset, matches the charge transfer resistance $\left(R_{2}\right)$ of the catalytic materials. It is 
clearly observed that the radii of the arc on the EIS Nyquist plots of $\mathrm{Co}_{3} \mathrm{O}_{4}(3) / l s m-\mathrm{TiO}_{2}$ are lower than those of pure $l s m-\mathrm{TiO}_{2}$, suggesting that the cobalt-doped samples possess smaller $\mathrm{R}_{\mathrm{ct}}$ and better electrochemical OER performance. Furthermore, the result indicates that $\mathrm{Co}_{3} \mathrm{O}_{4}(3) / l \mathrm{sm}-\mathrm{TiO}_{2}$ can accelerate charge transfer kinetics and acts as a highly effective water oxidation electrocatalyst. The $\mathrm{R}_{2}$ values for $\mathrm{Co}_{3} \mathrm{O}_{4}(3) / l s m-\mathrm{TiO}_{2}, \mathrm{Co}_{3} \mathrm{O}_{4}(3) / h m-\mathrm{TiO}_{2}, \mathrm{Co}_{3} \mathrm{O}_{4}(3) / b u l k-\mathrm{TiO}_{2}$, and $l s m-\mathrm{TiO}_{2}$ were found to be $7.10,184,723$, and $304 \Omega$, respectively, as shown in Table 4. The $\mathrm{Co}_{3} \mathrm{O}_{4}(3) / l s m-\mathrm{TiO}_{2}$ catalyst has the lowest $\mathrm{R}_{2}$ value, implying lower electron and charge transfer resistances and, thus, faster electrode kinetics, in agreement with its highest intrinsic activity toward the OER. Figure $7 \mathrm{~b}$ shows the Nyquist plots of the $\mathrm{Co}_{3} \mathrm{O}_{4}(3) / l s m-\mathrm{TiO}_{2}$ catalyst at different overpotentials, with the corresponding impedance parameters reported in Table 5. It is clear from Figure $7 \mathrm{~b}$ that the semicircle diameter and the $\mathrm{R}_{2}$ values are considerably decreased as the overpotential shifts from 220 to $350 \mathrm{mV}$ vs. RHE, indicating that the OER process is considerably improved at higher potentials, which corresponds to earlier polarization curves.
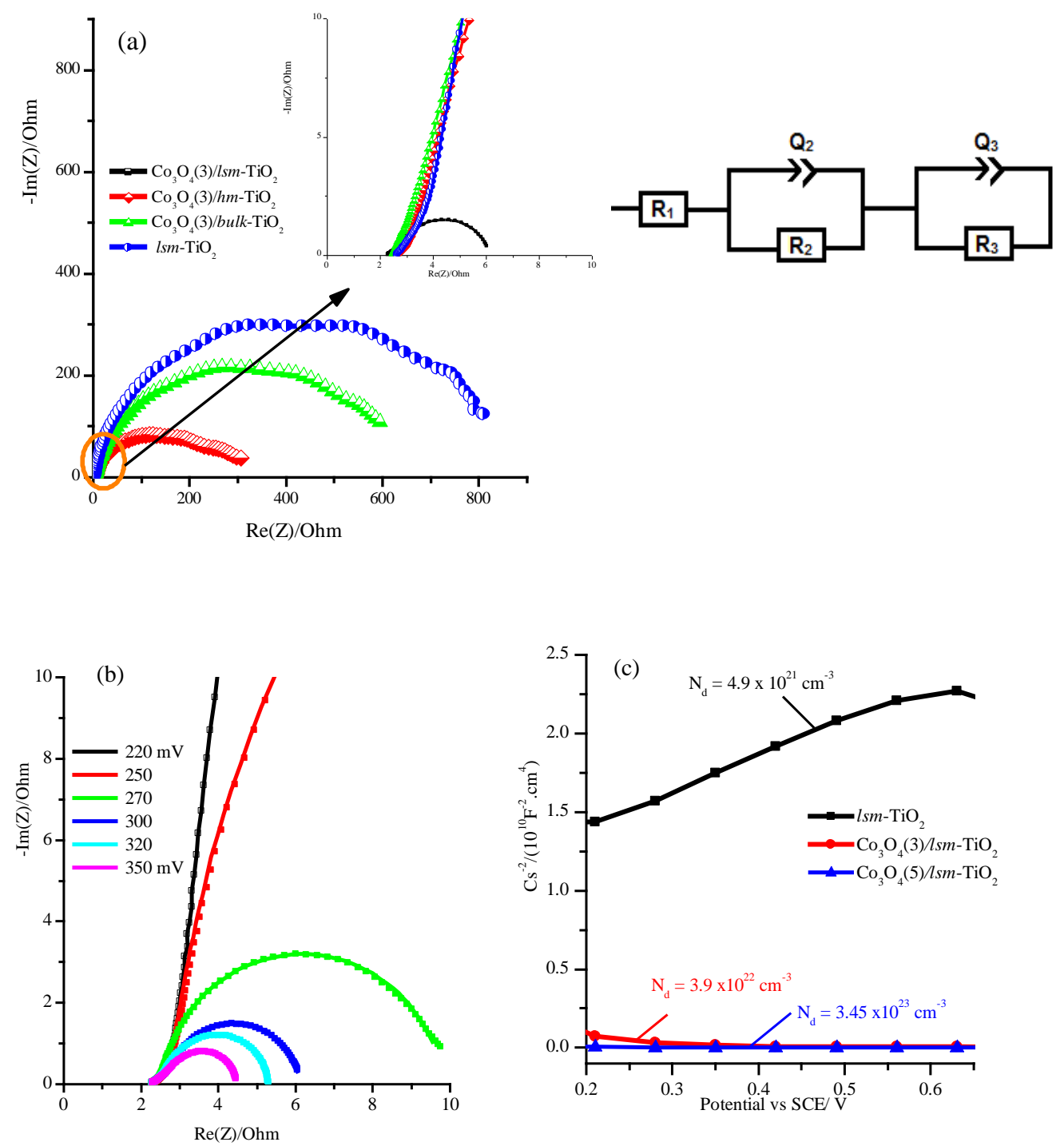

Figure 7. (a) Nyquist plots of $l s m-\mathrm{TiO}_{2}, \mathrm{Co}_{3} \mathrm{O}_{4}(3) / l s m-\mathrm{TiO}_{2}, \mathrm{Co}_{3} \mathrm{O}_{4}(3) / h m-\mathrm{TiO}_{2}$, and $\mathrm{Co}_{3} \mathrm{O}_{4}(3) / b u l k-\mathrm{TiO}_{2}$ electrodes in $1.0 \mathrm{M} \mathrm{KOH}$ solution, the inset is the equivalent circuit; (b) Nyquist plots of $\mathrm{Co}_{3} \mathrm{O}_{4}(3) / l s m-\mathrm{TiO}_{2}$ at different overpotential $(\eta)$; and (c) Mott-Schottky plot of pure $l s m-\mathrm{TiO}_{2}$, $\mathrm{Co}_{3} \mathrm{O}_{4}(3) / l s m-\mathrm{TiO}_{2}$ and $\mathrm{Co}_{3} \mathrm{O}_{4}(5) / l s m-\mathrm{TiO}_{2}$ electrodes measured at $500 \mathrm{~Hz}$. 
Although the Mott-Schottky (M-S) theory applies to the flat (non-porous) electrode, the M-S plot can be used to compare the apparent charge carrier density of the mesoporous catalysts [64]. Mott-Schottky (M-S) analysis was conducted on the pure $l s m-\mathrm{TiO}_{2}, \mathrm{Co}_{3} \mathrm{O}_{4}(3) / l s m-\mathrm{TiO}_{2}$, and $\mathrm{Co}_{3} \mathrm{O}_{4}(5) / l s m-\mathrm{TiO}_{2}$ catalysts. M-S plots were obtained in $1.0 \mathrm{M} \mathrm{KOH}$ at $500 \mathrm{~Hz}$ and are shown in Figure 7c. The pure $l s m-\mathrm{TiO}_{2}, \mathrm{Co}_{3} \mathrm{O}_{4}(3) / l s m-\mathrm{TiO}_{2}$, and $\mathrm{Co}_{3} \mathrm{O}_{4}(5) / l s m-\mathrm{TiO}_{2}$ catalysts clearly exhibit a positive slope in the $\mathrm{M}-\mathrm{S}$ curves, confirming n-type semiconductor character. Importantly, the $\mathrm{Co}_{3} \mathrm{O}_{4}(3) / l s m-\mathrm{TiO}_{2}$ and $\mathrm{Co}_{3} \mathrm{O}_{4}(5) / l s m-\mathrm{TiO}_{2}$ samples show substantially smaller slopes compared to pure $l s m-\mathrm{TiO}_{2}$, suggesting a significant increase in charge carrier density.

The catalysts carrier densities were estimated using the Mott-Schottky equation shown below:

$$
N_{d}=\left(\frac{2}{e_{0} \varepsilon \varepsilon_{0}}\right)\left[d\left(\frac{\frac{1}{C^{2}}}{d V}\right)^{-1}\right.
$$

where $\varepsilon_{0}$ is the permittivity of vacuum, $\mathrm{e}_{0}$ is the electron charge, $\varepsilon$ is the dielectric constant of $\mathrm{TiO}_{2}(31$ for anatase) [61], $\mathrm{V}$ is the applied electrode potential, and $\mathrm{N}_{\mathrm{d}}$ is the donor density. The Mott-Schottky plot with the corresponding charge carrier density value for all $\mathrm{Co}_{3} \mathrm{O}_{4}$ modified $l s m-\mathrm{TiO}_{2}$ electrodes is shown in Figure S6 (Supplementary Materials). The charge carrier densities of the pure $l s m-\mathrm{TiO}_{2}$, $\mathrm{Co}_{3} \mathrm{O}_{4}(3) / l \mathrm{sm}-\mathrm{TiO}_{2}, \mathrm{Co}_{3} \mathrm{O}_{4}(5) / l \mathrm{sm}-\mathrm{TiO}_{2}$, and $\mathrm{Co}_{3} \mathrm{O}_{4}(7) / l \mathrm{sm}-\mathrm{TiO}_{2}$ were estimated to be $4.9 \times 10^{21} \mathrm{~cm}^{-3}$, $3.9 \times 10^{22} \mathrm{~cm}^{-3}, 3.45 \times 10^{23} \mathrm{~cm}^{-3}$, and $2.24 \times 10^{22} \mathrm{~cm}^{-3}$, respectively. The increment in the carrier densities of $\mathrm{Co}_{3} \mathrm{O}_{4}(3) / l \mathrm{sm}-\mathrm{TiO}_{2}$ and $\mathrm{Co}_{3} \mathrm{O}_{4}(5) / l \mathrm{sm}-\mathrm{TiO}_{2}$ could be attributed to the increased oxygen vacancy states, which acted as extra electron donors for $\mathrm{TiO}_{2}$ substrate $[65,66]$.

Table 4. The EIS parameters of pure $l s m-\mathrm{TiO}_{2}, \mathrm{Co}_{3} \mathrm{O}_{4}(3) / l s m-\mathrm{TiO}_{2}, \mathrm{Co}_{2} \mathrm{O}_{3}(3) / h m-\mathrm{TiO}_{2}$, and $\mathrm{Co}_{2} \mathrm{O}_{3}(3) / b u l k-\mathrm{TiO}_{2}$ catalysts obtained through fitting EIS spectra measured at $\eta=500 \mathrm{mV}$ to an equivalent circuit.

\begin{tabular}{cccccc}
\hline Catalyst & $\mathbf{R}_{\mathbf{1}}(\boldsymbol{\Omega})$ & $\mathbf{Q}_{\mathbf{2}}\left(\boldsymbol{\mu} \mathbf{F} . \mathbf{s}^{\mathbf{n - 1}}\right)$ & $\mathbf{R}_{\mathbf{2}}(\boldsymbol{\Omega})$ & $\mathbf{Q}_{\mathbf{3}}\left(\boldsymbol{\mu} \mathbf{F} . \mathbf{s}^{\mathbf{n - 1}}\right)$ & $\mathbf{R}_{\mathbf{3}}(\boldsymbol{\Omega})$ \\
\hline$l s m-\mathrm{TiO}_{2}$ & 2.152 & 100 & 304 & 109 & 448 \\
$\mathrm{Co}_{3} \mathrm{O}_{4}(3) / l s m-\mathrm{TiO}_{2}$ & 2.260 & 10,140 & 7.10 & 9760 & 0.480 \\
$\mathrm{Co}_{3} \mathrm{O}_{4}(3) / h m-\mathrm{TiO}_{2}$ & 2.720 & 7170 & 184 & 3230 & 85 \\
$\mathrm{Co}_{3} \mathrm{O}_{4}(3) / b u l k-\mathrm{TiO}_{2}$ & 2.253 & 3870 & 723 & 190 & 110.4 \\
\hline
\end{tabular}

Table 5. The EIS extracted parameters from fitting EIS plots measured at different overpotential ( $\eta$ ) of $\mathrm{Co}_{3} \mathrm{O}_{4}(3) / l s m-\mathrm{TiO}_{2}$ catalyst.

\begin{tabular}{cccccc}
\hline Overpotential $(\eta) / \mathbf{m V}$ & $\mathbf{R}_{\mathbf{1}}(\boldsymbol{\Omega})$ & $\mathbf{Q}_{\mathbf{2}}\left(\mu \mathrm{F} . \mathbf{s}^{\mathbf{n - 1}}\right)$ & $\mathbf{R}_{\mathbf{2}}(\boldsymbol{\Omega})$ & $\mathbf{Q}_{\mathbf{3}}\left(\mu \mathrm{F} . \mathbf{s}^{\mathbf{n - 1}}\right)$ & $\mathbf{R}_{\mathbf{3}}(\boldsymbol{\Omega})$ \\
\hline 220 & 2.26 & 9370 & 299 & 104,000 & 0.95 \\
250 & 2.38 & 8890 & 53 & 4260 & 1.40 \\
280 & 2.26 & 10,140 & 7.1 & 9760 & 0.48 \\
300 & 2.41 & 12,650 & 3.90 & - & 3.4 \\
320 & 2.25 & 75,750 & 2.52 & 9806 & 2.52 \\
350 & 2.27 & 33,120 & 0.59 & 9840 & 1.69 \\
\hline
\end{tabular}

\subsection{Electrochemical Performance of the Mesoporous $\mathrm{TiO}_{2}$ Modified with Cobalt Oxide Nanoparticles for ORR}

The electrocatalytic ORR activity of $l s m-\mathrm{TiO}_{2}$ and $\mathrm{Co}_{3} \mathrm{O}_{4}(3) / l s m-\mathrm{TiO}_{2}$ was studied in an $\mathrm{N}_{2}$ - and $\mathrm{O}_{2}$-saturated $1.0 \mathrm{M} \mathrm{KOH}$ solution using glassy carbon electrode. As displayed in Figure $8 \mathrm{a}$, the curves show a distinctive ORR peak for $l s m-\mathrm{TiO}_{2}$ and $\mathrm{Co}_{3} \mathrm{O}_{4}(3) / l s m-\mathrm{TiO}_{2}$ electrodes in the $\mathrm{O}_{2}$-saturated electrolyte solution, which completely disappears in the $\mathrm{N}_{2}$-saturated $\mathrm{KOH}$ solution. Moreover, the oxygen reduction onset potential is at 0.84 and $0.73 \mathrm{~V}$ vs. RHE, and a peak current of $\sim 0.6$ and $\sim 0.2 \mathrm{~mA} \mathrm{~cm}^{-2}$ was obtained for $\mathrm{Co}_{3} \mathrm{O}_{4}(3) / l \mathrm{sm}$-and $l s m-\mathrm{TiO}_{2}$, respectively. This proves that $\mathrm{Co}_{3} \mathrm{O}_{4}(3) / l s m-\mathrm{TiO}_{2}$ significantly enhances the ORR in alkaline solution. Figure $8 \mathrm{~b}$ displays the LSV plots obtained using a glassy carbon rotating disk electrode (RDE) loaded with $l s m-\mathrm{TiO}_{2}, \mathrm{Co}_{3} \mathrm{O}_{4}(3) / b u l k-\mathrm{TiO}_{2}$, 
$\mathrm{Co}_{3} \mathrm{O}_{4}(3) / h m-\mathrm{TiO}_{2}$, and $\mathrm{Co}_{3} \mathrm{O}_{4}(3) / l s m-\mathrm{TiO}_{2}$ catalysts at a scan rate of $10 \mathrm{mV} \mathrm{s}^{-1}$ and a rotation speed of $2000 \mathrm{rpm}$ in $1.0 \mathrm{M} \mathrm{KOH}$ solution. The $\mathrm{Co}_{3} \mathrm{O}_{4}(3) / l \mathrm{sm}-\mathrm{TiO}_{2}$-based electrode achieved the best performance among the other investigated catalysts for the ORR in alkaline solution. As shown by the LSV curves of all investigated electrocatalysts (Figure $8 \mathrm{~b}$ ), the $\mathrm{Co}_{3} \mathrm{O}_{4}(3) / l s m-\mathrm{TiO}_{2}$-based electrode exhibits a high current density and a characteristic ORR onset potential of about $0.84 \mathrm{~V}$ vs. RHE, which is respectively 182,150 , and $140 \mathrm{mV}$ more positive than the overpotential of the $l s m$ - $\mathrm{TiO}_{2}$, $\mathrm{Co}_{3} \mathrm{O}_{4}(3) /$ bulk- $\mathrm{TiO}_{2}$, and $\mathrm{Co}_{3} \mathrm{O}_{4}(3) / h m-\mathrm{TiO}_{2}$ electrodes, respectively, signifying a more facile ORR process on $\mathrm{Co}_{3} \mathrm{O}_{4}(3) / l s m-\mathrm{TiO}_{2}$ hybrid.
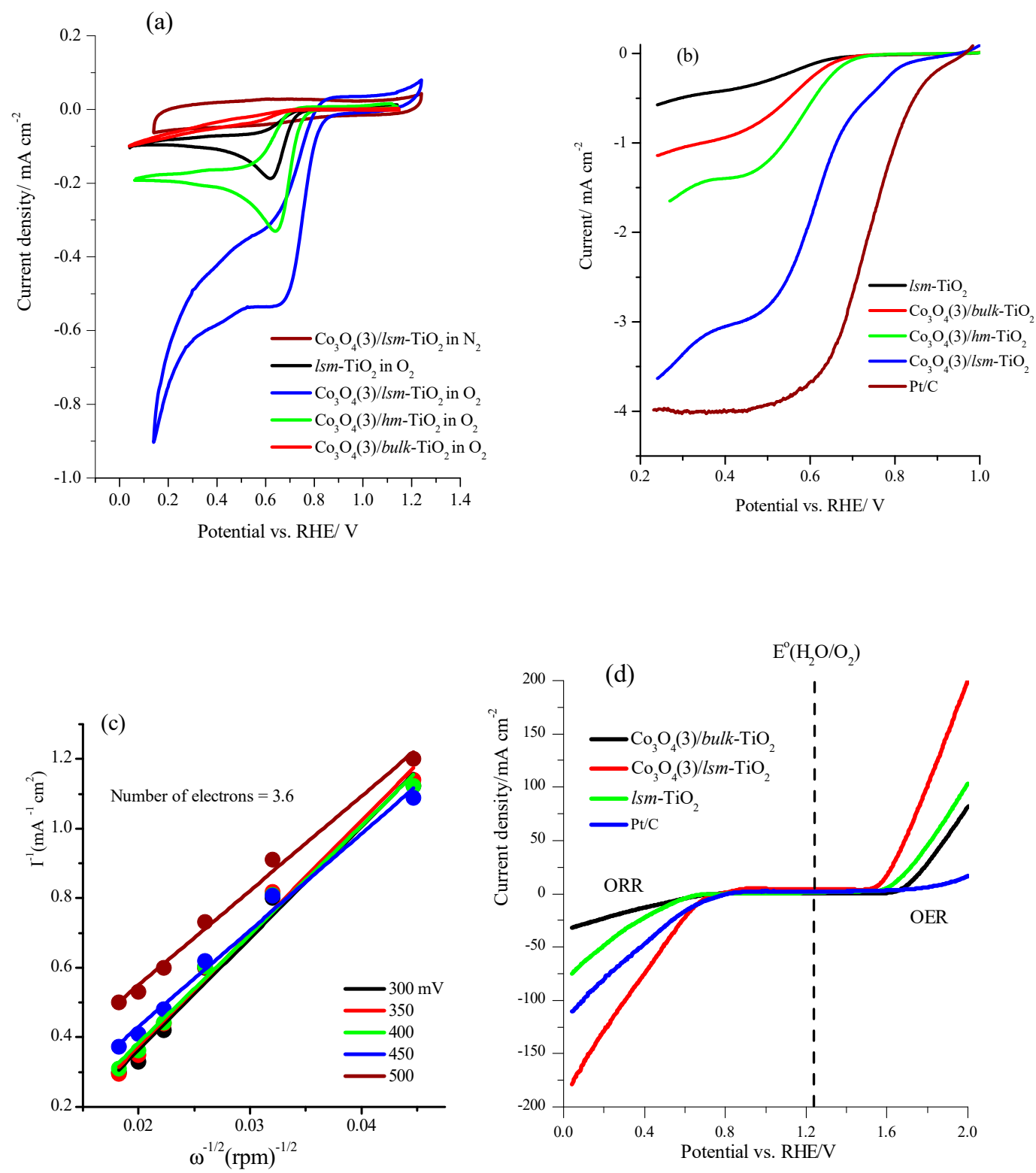

Figure 8. (a) Cathodic-going LSV curves at $10 \mathrm{mV} \mathrm{s}{ }^{-1}$ of $l s m-\mathrm{TiO}_{2}$ and $\mathrm{Co}_{3} \mathrm{O}_{4}(3) / l s m-\mathrm{TiO}_{2}$ catalysts loaded on GC electrode in $\mathrm{N}_{2}$ - and $\mathrm{O}_{2}$-saturated $1.0 \mathrm{M}$ of $\mathrm{KOH}$ solution; (b) the $\mathrm{LSV}$ plots of $l s m-\mathrm{TiO}_{2}$, $\mathrm{Co}_{3} \mathrm{O}_{4}(3) / b u l k-\mathrm{TiO}_{2}, \mathrm{Co}_{3} \mathrm{O}_{4}(3) / h m-\mathrm{TiO}_{2}$, and $\mathrm{Co}_{3} \mathrm{O}_{4}(3) / l s m-\mathrm{TiO}_{2}$, loaded on $\mathrm{GC}$ electrode at a scan rate of $10 \mathrm{mV} \mathrm{s}^{-1}$ and a rotation speed of $2000 \mathrm{rpm}$ in $1.0 \mathrm{M} \mathrm{KOH}$ solution; (c) the corresponding Koutecky-Levich (K-L) plots (at potentials of $0.25-0.5 \mathrm{~V}$ vs. RHE) for $\mathrm{Co}_{3} \mathrm{O}_{4}(3) / l s m-\mathrm{TiO}_{2}$ catalyst; (d) the LSV of both OER and ORR at scan rate of $10 \mathrm{mV} \mathrm{s}{ }^{-1}$ of $l s m-\mathrm{TiO}_{2}, \mathrm{Co}_{3} \mathrm{O}_{4}(3) / l s m-\mathrm{TiO}_{2}, \mathrm{Co}_{3} \mathrm{O}_{4}(3) / b u l k-\mathrm{TiO}_{2}$, and $\mathrm{Pt} / \mathrm{C}$ catalysts supported on $\mathrm{CP}$ electrode in $\mathrm{O}_{2}$-saturated $1.0 \mathrm{M} \mathrm{KOH}$ solution (the catalyst loading on the CP electrode was $0.8 \mathrm{mg} \mathrm{cm}^{-2}$ for all catalysts). 
Rotating disk electrode (RDE) analysis was also carried out to examine the ORR activity and kinetics of the $\mathrm{Co}_{3} \mathrm{O}_{4}(3) / \mathrm{lsm}$ - $\mathrm{TiO}_{2}$ electrode in an $\mathrm{O}_{2}$-saturated $1.0 \mathrm{M} \mathrm{KOH}$ solution. Figure $\mathrm{S} 7$ (Supplementary Materials) displays the LSV curves for $\mathrm{Co}_{3} \mathrm{O}_{4}(3) / l s m-\mathrm{TiO}_{2}$ at rotation speeds ranging from 500 to $3000 \mathrm{rpm}$. Evidently, as the rotational speed rate increases, the current density gradually increases, due to the enhanced mass transport to the electrode surface. The number of electrons transferred $(n)$ and participating in the ORR was assessed through the Koutecky-Levich (K-L) equation at different potentials and within the oxygen-limiting reduction current range, as shown in Figure 8c. From the line slope in Figure $8 \mathrm{c}$, the average $n$ value is about 3.6 at potentials varying from 0.25 to $0.5 \mathrm{~V}$ for the $\mathrm{Co}_{3} \mathrm{O}_{4}(3) / l \mathrm{sm}-\mathrm{TiO}_{2}$ catalyst. The calculated $n$ value of $\mathrm{Co}_{3} \mathrm{O}_{4}(3) / l s m-\mathrm{TiO}_{2}$ indicates a four-electron $\left(4 \mathrm{e}^{-}\right)$transfer reaction, suggesting a direct pathway for electrocatalytic reduction of oxygen forming water, rather than from hydrogen peroxide. The results of the OER and ORR studies confirm that the $\mathrm{Co}_{3} \mathrm{O}_{4}(3) / l s m-\mathrm{TiO}_{2}$ catalyst can be employed as a bifunctional oxygen electrocatalyst, and the electrocatalytic activity for both reactions can be assessed by the value of $\Delta \mathrm{E}$, which refers to the difference between the potential required to achieve $10 \mathrm{~mA} \mathrm{~cm}^{-2}\left(\mathrm{E}_{\mathrm{J} @ 10}\right)$ for the OER and the half-wave potential $\left(\mathrm{E}_{1 / 2}\right)$ for the ORR [67-71]. Figure 8d shows the $\mathrm{LSV}$ of $l s m-\mathrm{TiO}_{2}, \mathrm{Co}_{3} \mathrm{O}_{4}(3) / l s m-\mathrm{TiO}_{2}$, $\mathrm{Co}_{3} \mathrm{O}_{4}(3) / b u l k-\mathrm{TiO}_{2}$, and for comparison, the commercial $\mathrm{Pt} / \mathrm{C}$ catalysts loaded on carbon paper electrode in $\mathrm{O}_{2}$-saturated $1.0 \mathrm{M} \mathrm{KOH}$ solution at a scan rate of $10 \mathrm{mVs}^{-1}$. Compared with $\mathrm{Co}_{3} \mathrm{O}_{4}(3) / \mathrm{lsm}-\mathrm{TiO}_{2}$ that uses $\mathrm{P} 123$ as surfactant template, the $\mathrm{Co}_{3} \mathrm{O}_{4}(3) / b u l k-\mathrm{TiO}_{2}$ catalyst prepared in the absence of P123 surfactant exhibits lower ORR and OER activity due to particle aggregation, which inhibits the diffusion of $\mathrm{O}_{2}$ and induces the $\mathrm{O}_{2}$ reduction and evolution efficiencies. The $\mathrm{Co}_{3} \mathrm{O}_{4}(3) / l s m-\mathrm{TiO}_{2}$ exhibits the smallest $\Delta \mathrm{E}$ value of $0.92 \mathrm{~V}$ (with $\mathrm{E}_{\mathrm{J} @ 10}=1.55 \mathrm{~V}, \mathrm{E}_{1 / 2}=0.65 \mathrm{~V}$ ), and this value is noticeably lower than the $\Delta \mathrm{E}$ obtained using commercial $\mathrm{Pt} / \mathrm{C}$ catalyst $\left(1.19 \mathrm{~V}\right.$ with $\left.\mathrm{E}_{\mathrm{J} @ 10}=1.94 \mathrm{~V}, \mathrm{E}_{1 / 2}=0.75 \mathrm{~V}\right)$, $\mathrm{Co}_{3} \mathrm{O}_{4}(3) / h m-\mathrm{TiO}_{2}\left(0.99\right.$ with $\mathrm{E}_{\mathrm{J} @ 10}=1.69 \mathrm{~V}, \mathrm{E}_{1 / 2}=0.70 \mathrm{~V}$, not shown), $\mathrm{Co}_{3} \mathrm{O}_{4}(3) / b u l k-\mathrm{TiO}_{2}(1.14$ with $\left.\mathrm{E}_{\mathrm{J} @ 10}=1.69 \mathrm{~V}, \mathrm{E}_{1 / 2}=0.55 \mathrm{~V}\right)$, and $l s m-\mathrm{TiO}_{2}\left(1.18 \mathrm{~V}\right.$ with $\left.\mathrm{E}_{\mathrm{J} @ 10}=1.71 \mathrm{~V}, \mathrm{E}_{1 / 2}=0.53 \mathrm{~V}\right)$, and comparable with that of the state-of-the-art cobalt-based catalysts [67-71]. Interestingly, the ORR current density obtained at $\mathrm{Co}_{3} \mathrm{O}_{4}(3) / l s m-\mathrm{TiO}_{2}$ catalyst is higher than that at $\mathrm{Pt} / \mathrm{C}$ catalyst. These results illustrate the importance of the low-symmetry mesoporous $\mathrm{TiO}_{2}$ substrate and the role of cobalt oxide electrocatalyst dopants in boosting the ORR and OER activities for energy production and storage applications.

\section{Materials and Methods}

\subsection{Materials}

The triblock copolymer non-ionic surfactant of Pluronic ${ }^{\circledR}$ P123 (Mw = 5800, EO20PO70EO20) and titanium(IV) butoxide ( $\mathrm{TBO}, \mathrm{Ti}(\mathrm{OBu})_{4}, 97 \%$ ) were purchased from Sigma-Aldrich (Saint Louis, MO, USA). Cobalt acetate $\left(\mathrm{Co}(\mathrm{OAc})_{2} \cdot 4 \mathrm{H}_{2} \mathrm{O}\right)$ was purchased from Alfa Aesar (Ward Hill, MA, USA). Hydrochloric acid ( $\mathrm{HCl}, 37 \mathrm{wt} . \%)$, absolute ethanol $\left(\mathrm{C}_{2} \mathrm{H}_{6} \mathrm{O}\right.$, Analar), and acetylacetone (99\%) were all purchased from Sigma-Aldrich. Carbon paper (CP, SIGRACET, GDL-24BC, SGL Technologies, Wiesbaden, Germany) was employed as the working electrode substrate. Potassium hydroxide pellets (pure) was purchased from BDH group. Deionized water with a resistivity of $18.2 \mathrm{MOhm} \mathrm{cm}$ was obtained from Ultrapure Water purification system of Milli-Q (Millipore, Inc., Darmstadt, Germany).

\subsection{Synthesis of Cobalt Oxide/Mesoporous $\mathrm{TiO}_{2}$ Materials}

The crystalline mesoporous $\mathrm{Co}_{3} \mathrm{O}_{4}(x) / l s m-\mathrm{TiO}_{2}$ and $\mathrm{Co}_{3} \mathrm{O}_{4} / h m-\mathrm{TiO}_{2}$ catalysts $(x=0.5,1.0,3.0$, 5.0 and $7.0 \mathrm{wt} . \%$ of the cobalt precursor) were prepared according to our previous reports [36] by using a chelation-assisted evaporation-induced self-assembly (EISA) approach in an ethanolic/Pluronic ${ }^{\circledR}$ $\mathrm{P} 123 / \mathrm{HCl} /$ acetylacetone (AcAc)/titanium tetrabutoxide (TBO) mixed solution combined with a simple template-carbonization strategy. The low-symmetry mesoporous $\mathrm{TiO}_{2}$ modified with cobalt oxide nanoparticles was prepared by dissolving $0.50 \mathrm{~g}(0.086 \mathrm{mmol})$ of P123 surfactant in $10.0 \mathrm{~g}(217 \mathrm{mmol})$ of absolute ethanol. Then 7.5, 15.2, 46.579 .0 , and $113 \mathrm{mg}$ of $\mathrm{Co}(\mathrm{OAc})_{2}$ equivalent to 0.5, 1.0, 3.0, 5.0 , and $7.0 \mathrm{wt} . \%$ was added to the above solution with continuous vigorous stirring to attain a clear 
homogenous solution, which is denoted as solution-A. Next, $1.5 \mathrm{~g}$ of TBO was added to in AcAc solution with a TBO:AcAc ratio equal to $2: 3 \mathrm{wt} . \%$ and mixed for $20 \mathrm{~min}$ using magnetic stirring. Subsequently, the $\mathrm{TBO} / \mathrm{AcAc}$ mixture was slowly added to P123 solution while constantly stirring for $30 \mathrm{~min}$ at $25^{\circ} \mathrm{C}$ to obtain a homogeneous bright-yellow solution. In the meantime, concentrated $\mathrm{HCl}(1.5 \mathrm{~g}, 36 \mathrm{wt} . \%)$ was introduced dropwise, with continuous stirring, for a further $1.0 \mathrm{~h}$. Then the obtained homogeneous solution was decanted into Petri dishes to evaporate the solvents, and then subjected to heating in an oven at $40^{\circ} \mathrm{C}$ for $48 \mathrm{~h}$ for solidification and solvent evaporation. Later, the green transparent membrane was removed from the petri dish and subjected to pyrolysis at $350^{\circ} \mathrm{C}$ for $3.0 \mathrm{~h}$ under $\mathrm{N}_{2}$ atmosphere and a heating rate of $1{ }^{\circ} \mathrm{C} \mathrm{min}^{-1}$. Finally, the green mesoporous $\mathrm{Co}_{3} \mathrm{O}_{4}(x) / l s m-\mathrm{TiO}_{2}$ product was obtained by further calcination of the grey powder in the open air at $400{ }^{\circ} \mathrm{C}$ for $4.0 \mathrm{~h}$. The obtained cobalt oxide-modified low-symmetry mesoporous $\mathrm{TiO}_{2}$ material was labeled as $\mathrm{Co}_{3} \mathrm{O}_{4}(x) / \mathrm{Lsm}-\mathrm{TiO}_{2}$, in which $\mathrm{x}$ represents the weight percentage of the cobalt precursor used in the synthesis process $(0.5,1.0,3.0,5.0$, and $7.0 \mathrm{wt} . \%)$. In the absence of cobalt acetate addition, the sample was labeled as $l s m-\mathrm{TiO}_{2}$. The hexagonal mesoporous $\mathrm{TiO}_{2}$ modified by cobalt oxide $\left(\mathrm{Co}_{3} \mathrm{O}_{4}(\mathrm{x}) / \mathrm{hm}\right.$ - $\left.\mathrm{TiO}_{2}\right)$ catalyst was prepared by following the same procedure of self-assembly and heat treatment, but using $2.0 \mathrm{~g}$ of Pluronic ${ }^{\circledR}$ P123 $(0.159 \mathrm{mmol})$ surfactant with the addition of $2.4 \mathrm{~g}$ of concentrated $\mathrm{HCl}(36 \%)$. The non-porous catalyst $\left(\mathrm{Co}_{3} \mathrm{O}_{4} /\right.$ bulk- $\left.\mathrm{TiO}_{2}\right)$ was synthesized through a similar route, but without adding the Pluronic ${ }^{\circledR}$ P123 surfactant, and used as a control catalyst.

\subsection{Material Characterization}

The crystal structure of the catalysts was executed using X-ray diffraction (XRD, Rigaku Mini Flex 600, Tokyo, Japan) with $\mathrm{Cu} \mathrm{K} \alpha$ radiation $(40 \mathrm{kV}, 15 \mathrm{~mA})$. The crystallite size of the materials was calculated by the Scherrer equation as $D_{X R D}=0.94 \lambda / d \cos \theta$, where $\lambda$ is the $X$-ray wavelength, $\mathrm{d}$ is the diffraction peak width at half maximum, and $\theta$ is the diffraction angle. The catalysts surface morphology was acquired using scanning electron microscopy (Hitachi S4800, Japan) at $1.0 \mathrm{kV}$ and 10 mA. JEOL 2100F microscope (Tokyo, Japan) operated at $200 \mathrm{kV}$ was used to perform the catalysts' fine structures. The samples were dispersed in ethanol solution and supported onto a carbon film on a $\mathrm{Cu}$ grid to obtain for TEM measurement. X-ray photoelectron spectroscopy (XPS) analysis was performed using an Escalab 250 spectrometer (Thermo Fisher Scientific, Waltham, MA, USA) with an X-ray source of monochromatic $\mathrm{MgK}_{\alpha}$. The $\mathrm{N}_{2}$ adsorption-sorption isotherms at $77 \mathrm{~K}$ were measured using a NOVA 2200e surface area analyzer (Quantachrome Instruments, Florida, USA) Japan). Before the $\mathrm{N}_{2}$ sorption analysis, the catalyst materials were degassed under vacuum at $180{ }^{\circ} \mathrm{C}$ for $6 \mathrm{~h}$ and the surface area was assessed by the Brunauer-Emmett-Teller (BET) method and the pore size distribution and pore volume curves were estimated by the Barrett-Joyner-Halenda (BJH) method.

\subsection{Electrochemical Measurements}

The catalysts' electrochemical characterization was performed using a potentiostat (BioLogic SAS, model) in a 3-electrode assembly, with a Pt mesh $\left(1 \times 1 \mathrm{~cm}^{2}\right)$ and saturated calomel electrode (SCE) as the counter and reference electrodes, respectively. The mesoporous catalysts were deposited on a commercial carbon paper substrate $\left(\mathrm{CP}\right.$, SIGRACET ${ }^{\circledR}$, grade GDL-24BC, geometric area $\left.1 \times 1 \mathrm{~cm}^{2}\right)$ as the working electrode, while the potential was normalized to the reference hydrogen electrode (RHE) using the equation $\mathrm{E}_{\mathrm{RHE}}=\mathrm{E}_{\mathrm{SCE}}+0.244 \mathrm{~V}+0.059 \mathrm{pH}$ at $25^{\circ} \mathrm{C}$, where $\mathrm{pH}=14$ for $1.0 \mathrm{M} \mathrm{KOH}$ solution. The overpotential $(\eta)$ was estimated as $\mathrm{E}$ (vs. RHE) $-1.229 \mathrm{~V}$. The mesoporous catalyst was deposited on the CP electrode using the electrophoretic deposition (EPD) method. In a typical procedure, $1.0 \mathrm{~mL}$ of iodine ( $40 \mathrm{mg}$ in $15 \mathrm{~mL}$ acetone) was mixed with $15 \mathrm{mg}$ of mesoporous catalyst powder and dispersed using an ultrasonic probe for $20 \mathrm{~min}$ to get a uniformly dispersed mixture of catalyst powder. The $\mathrm{CP}$ substrate $\left(1 \times 1 \mathrm{~cm}^{2}\right)$ was placed in a small glass cell as the cathode and in parallel with the CP anode at a distance of ca. $1 \mathrm{~cm}$. Then, a bias of $+10 \mathrm{~V}$ was applied between them for $4 \mathrm{~min}$ using BioLogic SAS potentiostat to deposit the catalyst particles. Subsequently, the working electrode was rinsed with deionized water, dried in air, and calcined in a tube furnace under $\mathrm{N}_{2}$ flow at $350{ }^{\circ} \mathrm{C}$ for $30 \mathrm{~min}$. 
The average weight of the catalyst deposited on $\mathrm{CP}$ was $0.4 \mathrm{mg}$. The polarization curves and the OER and the ORR activity were reported without IR correction. Impedance spectroscopy analysis was executed in the frequency range of $10^{-2}$ to $200 \mathrm{kHz}$ with an AC voltage amplitude of $20 \mathrm{mV}$ at a bias of $0.5 \mathrm{~V}$ vs. SCE in a $1.0 \mathrm{M} \mathrm{KOH}$ electrolyte. Mott-Schottky (M-S) plots were acquired in direct current potential polarization with a potential step of $10 \mathrm{mV}$ at $500 \mathrm{~Hz}$. The commercial Pt/C (10 wt.\%) and $\mathrm{IrO}_{2}$ catalysts were prepared and tested, under similar conditions for the sake of comparison. For ORR, linear sweep voltammetry (LSV) and cyclic voltammetry polarization measurements were performed in an $\mathrm{O}_{2}$-saturated (if applicable) $1.0 \mathrm{M}$ of $\mathrm{KOH}$ solution at $10 \mathrm{mV} \mathrm{s}^{-1}$. The catalyst ink was made by dispersing the electrocatalyst $(10 \mathrm{mg})$ in a mixture of water $(0.5 \mathrm{~mL})$, isopropanol $(0.5 \mathrm{~mL})$, and Nafion $(10 \mu \mathrm{L}$ of $5 \mathrm{wt} . \%$ ) followed by sonication for $20 \mathrm{~min}$. Afterwards, the catalyst ink (5 $\mu \mathrm{L}$, equivalent to $50 \mu \mathrm{g}$ ) was casted on a glassy carbon (GC) electrode (diameter $=3 \mathrm{~mm}$, area $=0.07 \mathrm{~cm}^{2}$ ). Rotating disk electrode (RDE) experiments were recorded using glassy carbon ( $3.0 \mathrm{~mm}$ diameter, METROHM, 628-10) at a rotation speed range of 500 to $3000 \mathrm{rpm}$ at $10 \mathrm{mV} \mathrm{s}^{-1}$. Furthermore, the total number of electrons taking part in the ORR was assessed via the Koutecky-Levich $(\mathrm{K}-\mathrm{L})$ equation shown below:

$$
\begin{gathered}
\frac{1}{J}=\frac{1}{J_{L}}+\frac{1}{J_{K}}=\frac{1}{B \omega^{1 / 2}}+\frac{1}{J_{K}} \\
B=0.62 n F C_{0}\left(D_{0}\right)^{2 / 3} v^{-1 / 6}
\end{gathered}
$$

where $\mathrm{J}_{\mathrm{K}}$ and $\mathrm{J}_{\mathrm{L}}$ are the kinetic and limiting current densities, respectively; $\omega$ is the electrode rotating rate; $\mathrm{B}$ is determined from the slope of K-L curves according to the Levich formula (1); $\mathrm{F}$ is the Faraday constant, $96485 \mathrm{C}$ mole ${ }^{-1} ; \mathrm{n}$ is the number of electrons transferred; $\mathrm{C}_{0}$ is the bulk concentration of $\mathrm{O}_{2}$, $1.2 \times 10^{-6}$ mole cm${ }^{-3} ; v$ is the kinetic viscosity, $1.01 \times 10^{-2} \mathrm{~cm}^{2} \mathrm{~s}^{-1}$; and $\mathrm{D}_{0}$ is the diffusion coefficient of $\mathrm{O}_{2}, 1.97 \times 10^{-5} \mathrm{~cm}^{2} \mathrm{~s}^{-1}$.

\section{Conclusions}

In conclusion, we have demonstrated the synthesis of highly active bifunctional OER/ORR hybrids of cobalt oxide-doped low-symmetry mesoporous titanium oxide $\left(\mathrm{Co}_{3} \mathrm{O}_{4}(x) / l s m\right.$ - $\left.\mathrm{TiO}_{2}\right)$ catalysts via the self-assembly surfactant template method. The effects of cobalt doping level on the morphology and electrocatalytic properties of the obtained mesoporous hybrids were investigated. The hybrids' characterizations confirmed the formation of mesoporous titanium dioxide substrate modified with cobalt oxide nanoparticles with a diameter of $2-3 \mathrm{~nm}$. The $\mathrm{Co}_{3} \mathrm{O}_{4}(3) / 1 \mathrm{sm}-\mathrm{TiO}_{2}$ hybrid with $\sim 3 \mathrm{wt} . \% \mathrm{Co}$ doping was found to be a highly active electrocatalyst for both the OER and the ORR in alkaline media. This catalyst exhibited excellent bifunctional OER/ORR catalytic performance, low onset potentials (1.480 V OER and 0.84 V ORR), a small OER/ORR overpotential gap $(\Delta \mathrm{E})$ of $0.92 \mathrm{~V}$, which is significantly lower than that of reference analogue of $\left(l s m-\mathrm{TiO}_{2}(1.18 \mathrm{~V}), \mathrm{Co}_{3} \mathrm{O}_{4}(3) / b u l k-\mathrm{TiO}_{2}(1.14 \mathrm{~V})\right.$ hybrids, the noble-metal catalyst of $\mathrm{Pt} / \mathrm{C}(1.19 \mathrm{~V})$, and better durability in comparison with $\mathrm{IrO}_{2}$. The enhanced activity of $\mathrm{Co}_{3} \mathrm{O}_{4}(3) / l s m-\mathrm{TiO}_{2}$ catalyst is believed to originate from the synergetic effect between $\mathrm{Co}_{3} \mathrm{O}_{4}$ and $\mathrm{TiO}_{2}$, higher charge carrier density, as well as the presence of short-range order mesopores and channels which provide short ions diffusion path during the electrocatalytic process. Our results support the new approach to fabricating novel $\mathrm{TiO}_{2}$-based bifunctional OER and ORR catalysts modified with non-precious metal oxides for energy production, storage, and conversion technologies.

Supplementary Materials: The following are available online at http://www.mdpi.com/2073-4344/9/10/836/s1: Figure S1: SEM image for $\mathrm{Co}_{3} \mathrm{O}_{4}(7) / l s m-\mathrm{TiO}_{2}$ with cobalt oxide highlighted with yellow circles; Figure S2: XRD spectra of $\mathrm{Co}_{3} \mathrm{O}_{4}(3) / l s m-\mathrm{TiO}_{2}, \mathrm{Co}_{3} \mathrm{O}_{4}(3) / h m-\mathrm{TiO}_{2}$, and $\mathrm{Co}_{3} \mathrm{O}_{4}(3) / b u l k-\mathrm{TiO}_{2} ;$ Figure S3: Plot for the effect of varying cobalt content on the average crystallite size of the $\mathrm{Co}_{3} \mathrm{O}_{4}(x) / l \mathrm{sm}-\mathrm{TiO}_{2}$ catalysts; Figure S4: SEM-EDX elements mapping of $\mathrm{Co}(3) / \mathrm{hm}-\mathrm{TiO}_{2}$; Figure S5: SEM-EDX elements mapping of $\mathrm{Co}(3) / l \mathrm{sm}-\mathrm{TiO}_{2}$ catalyst; Figure S6: Mott-Schottky plot of pure $l s m-\mathrm{TiO}_{2}$ and $\mathrm{Co}_{3} \mathrm{O}_{4}$-modified $l s m-\mathrm{TiO}_{2}$ electrodes measured at $500 \mathrm{~Hz} ;$ Figure S7: LSV curves of $\mathrm{Co}_{3} \mathrm{O}_{4}(3) / l s m-\mathrm{TiO}_{2}$ at a scan rate of $10 \mathrm{mV} \mathrm{s}^{-1}$ and a rotation speed of 500, 1000, 1500, 2000, 2500, and $3000 \mathrm{rpm}$ in $\mathrm{O}_{2}$-saturated $1.0 \mathrm{M} \mathrm{KOH}$; Table S1: The atomic contents of $\mathrm{Co}$, Ti, and $\mathrm{O}$ in $l \mathrm{sm}$ - $\mathrm{TiO}_{2}$ and $\mathrm{Co}(3) / l s m-\mathrm{TiO}_{2}$ according to the XPS reports; Table S2: Comparison of OER performance for $\mathrm{Co}_{3} \mathrm{O}_{4}(3) / l s m-\mathrm{TiO}{ }_{2}$ with other reported OER electrocatalysts in alkaline media. Turnover frequency (TOF) calculation method. 
Author Contributions: M.S.A. executed the experimental part and prepared the original draft; M.A.G. drew the conceptualization plan, preformed analysis and validated the results, and wrote and edited the manuscript in the final form; P.A. performed and analyses in the ISE part; S.M.H. executed and wrote the XPS analysis part; and A.M.A.-M. provided the funds, resources, and supervision for the overall research project.

Funding: This research was funded by King Saud University, the Vice Deanship of Scientific Research Chairs.

Acknowledgments: The authors are grateful to the Deanship of Scientific Research, King Saud University for funding through the Vice Deanship of Scientific Research Chairs, and they thank the Researchers Support \& Services Unit (RSSU) for the manuscript proofreading.

Conflicts of Interest: The authors declare no conflicts of interest.

\section{References}

1. Hong, W.T.; Risch, M.; Stoerzinger, K.A.; Grimaud, A.; Suntivich, J.; Shao-Horn, Y. Toward the rational design of non-precious transition metal oxides for oxygen electrocatalysis. Energy Environ. Sci. 2015, 8, 1404-1427. [CrossRef]

2. Qian, Y.; Hu, Z.; Ge, X.; Yang, S.; Peng, Y.; Kang, Z.; Liu, Z.; Lee, J.Y.; Zhao, N.Y. A metal-free ORR/OER bifunctional electrocatalyst derived from metal-organic frameworks for rechargeable Zn-Air batteries. Carbon 2017, 111, 641-650. [CrossRef]

3. Girishkumar, G.; McCloskey, B.; Luntz, A.C.; Swanson, S.; Wilcke, W. Lithium-air battery: Promise and challenges. J. Phys. Chem. Lett. 2010, 1, 2193-2203. [CrossRef]

4. Stambouli, A.B.; Traversa, E. Solid oxide fuel cells (SOFCs): A review of an environmentally clean and efficient source of energy, Renewable Sustainable. Energy Rev. 2002, 6, 433-455. [CrossRef]

5. Sivanantham, A.; Ganesan, P.; Shanmugam, S. Hierarchical $\mathrm{NiCo}_{2} \mathrm{~S}_{4}$ Nanowire Arrays Supported on Ni Foam: An Efficient and Durable Bifunctional Electrocatalyst for Oxygen and Hydrogen Evolution Reactions. Adv. Funct. Mater. 2016, 26, 4661-4672. [CrossRef]

6. Liu, Q.; Xie, L.; Liu, Z.; Du, G.; Asiri, A.M.; Sun, X. Zn-doped $\mathrm{Ni}_{3} \mathrm{~S}_{2}$ nanosheets array as a high-performance electrochemical water oxidation catalyst in alkaline solution. Chem. Commun. 2017, 53, 12446-12449. [CrossRef]

7. Grimaud, A.; Diaz-Morales, O.; Han, B.; Hong, W.T.; Lee, Y.L.; Giordano, L.; Stoerzinger, K.A.; Koper, M.T.M.; Shao-Horn, Y. Activating lattice oxygen redox reactions in metal oxides to catalyse oxygen evolution. Nat. Chem. 2017, 9, 457-465. [CrossRef]

8. Yin, Q.; Tan, J.M.; Besson, C.; Geletii, Y.V.; Musaev, D.G.; Kuznetsov, A.E.; Luo, Z.; Hardcastle, K.I.; Hill, C.L. A fast soluble carbon-free molecular water oxidation catalyst based on abundant metals. Science 2010, 328, 342-345. [CrossRef]

9. Liu, Y.; Wang, H.; Lin, D.; Liu, C.; Hsu, P.C.; Liu, W.; Chen, W.; Cui, Y. Electrochemical tuning of olivine-type lithium transition-metal phosphates as efficient water oxidation catalysts. Energy Environ. Sci. 2015, 8, 1719-1724. [CrossRef]

10. McCrory, C.C.L.; Jung, S.; Ferrer, I.M.; Chatman, S.M.; Peters, J.C.; Jaramillo, T.F. Benchmarking hydrogen evolving reaction and oxygen evolving reaction electrocatalysts for solar water splitting devices. J. Am. Chem. Soc. 2015, 137, 4347-4357. [CrossRef]

11. Caro, C.; Thirunavukkarasu, K.; Anilkumar, M.; Shiju, N.R.; Rothenberg, G. Selective Autooxidation of Ethanol over Titania-Supported Molybdenum Oxide Catalysts: Structure and Reactivity. Adv. Synth. Catal. 2012, 354, 1327-1336. [CrossRef] [PubMed]

12. Caro, C.; Gámez, F.; Sayagues, M.J.; Polvillo, R.; Royo, J.L. AgACTiO 2 nanoparticles with microbiocide properties under visible light. Mater. Res. Express 2015, 2, 055002. [CrossRef]

13. Zhang, W.; Innocenti, G.; Ferbinteanu, M.; Ramos-Fernandez, E.V.; Sepulveda-Escribano, A.; Wu, H.; Cavani, F.; Rothenberg, G.; Shiju, N.R. Understanding the oxidative dehydrogenation of ethyl lactate to ethyl pyruvate over vanadia/titania. Catal. Sci. Technol. 2018, 8, 3737-3747. [CrossRef]

14. Lee, Y.; Suntivich, J.; May, K.J.; Perry, E.E.; Shao-Horn, Y. Synthesis and activities of rutile $\mathrm{IrO}_{2}$ and $\mathrm{RuO}_{2}$ nanoparticles for oxygen evolution in acid and alkaline solutions. J. Phys. Chem. Lett. 2012, 3, 399-404. [CrossRef] [PubMed]

15. Ghanem, M.A.; Arunachalam, P.; Almayouf, A.; Weller, M.T. Efficient Bi-Functional Electrocatalysts of Strontium Iron Oxy-Halides for Oxygen Evolution and Reduction Reactions in Alkaline Media. J. Electrochem. Soc. 2016, 163, H450-H458. [CrossRef] 
16. Deng, X.; Tüysüz, H. Cobalt-Oxide-Based Materials as Water Oxidation Catalyst: Recent Progress and Challenges. ACS Catal. 2014, 4, 3701-3714. [CrossRef]

17. Zhang, G.; Xia, B.Y.; Wang, X.; Lou, X.W. Strongly coupled $\mathrm{NiCo}_{2} \mathrm{O}_{4}-\mathrm{rGO}$ hybrid nanosheets as a methanol-tolerant electrocatalyst for the oxygen reduction reaction. Adv. Mater. 2014, 26, 2408-2412. [CrossRef]

18. Wang, Y.; Zhang, Y.; Liu, Z.; Xie, C.; Feng, S.; Liu, D.; Shao, M.; Wang, S. Layered double hydroxide nanosheets with multiple vacancies obtained by dry exfoliation as highly efficient oxygen evolution electrocatalysts. Angew. Chem. Int. Ed. 2017, 56, 5867-5871. [CrossRef]

19. Duarte, M.F.P.; Rocha, I.M.; Figueiredo, J.L.; Freire, C.; Pereira, M.F.R. CoMn-LDH@carbon nanotube composites: Bifunctional electrocatalysts for oxygen reactions. Catal. Today 2018, 301, 17-24. [CrossRef]

20. Wang, Y.; Hu, T.; Liu, Q.; Zhang, L. $\mathrm{CoMn}_{2} \mathrm{O}_{4}$ embedded in $\mathrm{MnOOH}$ nanorods as a bifunctional catalyst for oxygen reduction and oxygen evolution reactions. Chem. Commun. 2018, 54, 4005-4008. [CrossRef]

21. Liang, Y.; Li, Y.; Wang, H.; Zhou, J.; Wang, J.; Regier, T.; Dai, $\mathrm{H} \mathrm{Co}_{3} \mathrm{O}_{4}$ nanocrystals on graphene as a synergistic catalyst for oxygen reduction reaction. Nat. Mater. 2011, 10, 780-786. [CrossRef] [PubMed]

22. Oh, T.; Kim, K.; Kim, J. Controllable active sites and facile synthesis of cobalt nanoparticle embedded in nitrogen and sulfur co-doped carbon nanotubes as efficient bifunctional electrocatalysts for oxygen reduction and evolution reactions. J. Energy Chem. 2019, 38, 60-67. [CrossRef]

23. Kuang, M.; Zheng, G. Nanostructured bifunctional redox electrocatalysts. Small 2016, 12, 5656-5675. [CrossRef] [PubMed]

24. Huang, Z.F.; Wang, J.; Peng, Y.; Jung, C.Y.; Fisher, A.; Wang, X. Design of efficient bifunctional oxygen reduction/evolution electrocatalyst: Recent advances and perspectives. Adv. Energy Mater. 2017, 7, 1700544. [CrossRef]

25. Shang, L.; Yu, H.; Huang, X.; Bian, T.; Shi, R.; Zhao, Y.; Waterhouse, G.I.N.; Wu, L.Z.; Tung, C.H.; Zhang, T. Well-dispersed ZIF-derived Co, N-Co-doped carbon nanoframes through mesoporous-silica-protected calcination as efficient oxygen reduction electrocatalysts. Adv. Mater. 2016, 28, 1668-1674. [CrossRef] [PubMed]

26. Hu, Y.; Liu, Y.; Sun, Y. Mesoporous Colloidal Superparticles of Platinum-Group Nanocrystals with Surfactant-Free Surfaces and Enhanced Heterogeneous Catalysis. Adv. Funct. Mater. 2015, 25, 1638-1647. [CrossRef]

27. Wu, Z.; Zhao, D. Ordered mesoporous materials as adsorbents. Chem. Commun. 2011, 47, 3332-3338. [CrossRef]

28. Knossalla, J.; Mezzavilla, S.; Schüth, F. Continuous synthesis of nanostructured silica-based materials in a gas-liquid segmented flow tubular reactor. New J. Chem. 2016, 40, 4361-4366. [CrossRef]

29. Song, W.; Ren, Z.; Chen, S.Y.; Meng, Y.; Biswas, S.; Nandi, P.; Elsen, H.A.; Gao, P.X.; Suib, S.L. Ni- and Mn-promoted mesoporous $\mathrm{Co}_{3} \mathrm{O}_{4}$ : A stable bifunctional catalyst with surface-structure-dependent activity for oxygen reduction reaction and oxygen evolution reaction. ACS Appl. Mater. Interfaces 2016, 8, 20802-20813. [CrossRef]

30. Sa, Y.J.; Kwon, K.; Cheon, J.Y.; Kleitz, F.; Joo, S.H. Ordered mesoporous $\mathrm{Co}_{3} \mathrm{O}_{4}$ spinels as stable, bifunctional, noble metal-free oxygen electrocatalysts. J. Mater. Chem. A 2013, 1, 9992-10001. [CrossRef]

31. Amer, M.S.; Ghanem, M.A.; Al-Mayouf, A.M.; Arunachalam, P.; Khdary, N. Low-loading of oxidized platinum nanoparticles into mesoporous titanium dioxide for effective and durable hydrogen evolution in acidic media. Arab. J. Chem. 2018. [CrossRef]

32. Mosa, I.M.; Biswas, S.; El-Sawy, A.M.; Botu, V.; Guild, C.; Song, W.; Ramprasad, R.; Rusling, J.F.; Suib, S.L. Tunable mesoporous manganese oxide for high-performance oxygen reduction and evolution reactions. J. Mater. Chem. A 2015, 4, 620-631. [CrossRef]

33. Zhou, W.; Li, W.; Wang, J.Q.; Qu, Y.; Yang, Y.; Xie, Y.; Zhang, K.; Wang, L.; Fu, H.; Zhao, D. Ordered mesoporous black $\mathrm{TiO}_{2}$ as highly efficient hydrogen evolution photocatalyst. J. Am. Chem. Soc. 2014, 136, 9280-9283. [CrossRef] [PubMed]

34. Hartmann, P.; Lee, D.K.; Smarsly, B.M.; Janek, J. Mesoporous $\mathrm{TiO}_{2}$ : Comparison of classical sol-gel and nanoparticle-based photoelectrodes for the water splitting reaction. ACS Nano 2010, 4, 3147-3154. [CrossRef] [PubMed] 
35. Amer, M.S.; Ghanem, M.A.; Al-Mayouf, A.M.; Arunachalam, P. Low-symmetry mesoporous titanium dioxide $\left(\mathrm{lsm}-\mathrm{TiO}_{2}\right)$ electrocatalyst for efficient and durable oxygen evolution in aqueous alkali. J. Electrochem. Soc. 2018, 165, H300-H309. [CrossRef]

36. Ghanem, M.A.; Arunachalam, P.; Amer, M.S.; Al-Mayouf, A.M. Mesoporous titanium dioxide photoanodes decorated with gold nanoparticles for boosting the photoelectrochemical alkali water oxidation. Mater. Chem. Phys. 2018, 213, 56-66. [CrossRef]

37. Liu, B.; Chen, H.M.; Liu, C.; Andrews, S.C.; Hahn, C.; Yang, P. Large-scale synthesis of transition-metal-doped $\mathrm{TiO}_{2}$ nanowires with controllable overpotential. J. Am. Chem. Soc. 2013, 135, 9995-9998. [CrossRef] [PubMed]

38. Jang, D.M.; Kwak, I.H.; Kwon, E.L.; Jung, C.S.; Im, H.S.; Park, K.; Park, J. Transition-metal doping of oxide nanocrystals for enhanced catalytic oxygen evolution. J. Phys. Chem. C 2015, 119, 1921-1927. [CrossRef]

39. Cai, L.; Cho, I.S.; Logar, M.; Mehta, A.; He, J.; Lee, C.H.; Rao, P.M.; Feng, Y.; Wilcox, J.; Prinz, F.B.; et al. Sol-flame synthesis of cobalt-doped $\mathrm{TiO}_{2}$ nanowires with enhanced electrocatalytic activity for oxygen evolution reaction. Phys. Chem. Chem. Phys. 2014, 16, 12299-12306. [CrossRef]

40. Roy, N.; Sohn, Y.; Leung, K.T.; Pradhan, D. Engineered electronic states of transition metal doped $\mathrm{TiO}_{2}$ nanocrystals for low overpotential oxygen evolution reaction. J. Phys. Chem. C 2014, 118, 29499-29506. [CrossRef]

41. García-Mota, M.; Vojvodic, A.; Metiu, H.; Man, I.C.; Su, H.Y.; Rossmeisl, J.; Nørskov, J.K. Tailoring the activity for oxygen evolution electrocatalysis on rutile $\mathrm{TiO}_{2}(110)$ by transition-metal substitution. ChemCatChem 2011, 3, 1607-1611. [CrossRef]

42. Han, L.N.; Lv, L.B.; Zhu, Q.C.; Wei, X.; Li, X.H.; Chen, J.S. Ultra-durable two-electrode Zn-air secondary batteries based on bifunctional titania nanocatalysts: $\mathrm{Co}^{2+}$ dopant boosts the electrochemical activity. J. Mater. Chem. A 2016, 4, 7841-7847. [CrossRef]

43. Yang, Y.; Kao, L.C.; Liu, Y.; Sun, K.; Yu, H.; Guo, J.; Liou, S.Y.H.; Hoffmann, M.R. Modification of mesoporous titanium dioxide with cobalt oxide electrocatalyst for enhanced oxygen evolution reaction. ACS Catal. 2018, 8, 4278-4287. [CrossRef] [PubMed]

44. Wu, Q.L.; Rankin, S.E. Tuning the mesopore size of titania thin films using a polymeric swelling agent. J. Phys. Chem. C 2011, 115, 11925-11933. [CrossRef]

45. Crepaldi, E.L.; Soler-Illia, G.J.D.A.; Grosso, D.; Cagnol, F.; Ribot, F.; Sanchez, C. Controlled formation of highly organized mesoporous titania thin films: From mesostructured hybrids to mesoporous nanoanatase $\mathrm{TiO}_{2}$. J. Am. Chem. Soc. 2003, 125, 9770-9786. [CrossRef] [PubMed]

46. Alberius, P.C.; Frindell, K.L.; Hayward, R.C.; Kramer, E.J.; Stucky, G.D.; Chmelka, B.F. General predictive syntheses of cubic, hexagonal, and lamellar silica and titania mesostructured thin films. Chem. Mater. 2002, 14, 3284-3294. [CrossRef]

47. Wang, T.; Meng, X.; Liu, G.; Chang, K.; Li, P.; Kang, Q.; Liu, L.; Li, M.; Ouyang, S.; Ye, J. In situ synthesis of ordered mesoporous $\mathrm{Co}$-doped $\mathrm{TiO}_{2}$ and its enhanced photocatalytic activity and selectivity for the reduction of $\mathrm{CO}_{2}$. J. Mater. Chem. A 2015, 3, 9491-9501. [CrossRef]

48. Papageorgiou, A.C.; Cabailh, G.; Chen, Q.; Resta, A.; Lundgren, E.; Andersen, J.N.; Thornton, G. Growth and reactivity of titanium oxide ultrathin films on Ni(110). J. Phys. Chem. C 2007, 111, 7704-7710. [CrossRef]

49. Wang, G.M.; Wang, H.; Ling, Y.; Tang, Y.; Yang, X.; Fitzmorris, R.C.; Wang, C.; Zhang, J.Z.; Li, Y. Hydrogen-Treated $\mathrm{TiO}_{2}$ Nanowire Arrays for Photoelectrochemical Water Splitting. Nano Lett. 2011, 11, 3026-3033. [CrossRef]

50. Liu, D.; Zhang, Y.; Xiao, P.; Garcia, B.B.; Zhang, Q.; Zhou, X.; Cao, G. $\mathrm{TiO}_{2}$ nanotube arrays annealed in $\mathrm{CO}$ exhibiting high performance for lithium ion intercalation. Tech. Proc. 2009, 3, 50-57. [CrossRef]

51. Chen, C.J.; Wen, Y.W.; Hu, X.L.; Ji, X.L.; Yan, M.Y.; Mai, L.Q.; Hu, P.; Shan, B.; Huang, Y.H. Na ${ }^{+}$intercalation pseudocapacitance in graphene-coupled titanium oxide enabling ultra-fast sodium storage and long-term cycling. Nat. Commun. 2015, 6, 69297. [CrossRef] [PubMed]

52. Lazarus, M.S.; Sham, T.K. X-ray photoelectron spectroscopy (XPS) studies of hydrogen reduced rutile $\left(\mathrm{TiO}_{2-\mathrm{x}}\right)$ surfaces. Chem. Phys. Lett. 1982, 92, 670-674. [CrossRef]

53. McCafferty, E.; Wightman, J.P. Determination of the concentration of surface hydroxyl groups on metal oxide films by a quantitative XPS method. Surf. Interface Anal. 1998, 26, 549-564. [CrossRef]

54. Feng, D.; Gao, T.N.; Fan, M.; Li, A.; Li, K.; Wang, T.; Huo, Q.; Qiao, Z.A. A general ligand-assisted self-assembly approach to crystalline mesoporous metal oxides. NPG Asia Mater. 2018, 10, 800-809. [CrossRef] 
55. Kruk, M.; Jaroniec, M.; Guan, S.; Inagaki, S. Gas Adsorption Characterization of Ordered Organic-Inorganic Nanocomposite Materials. Chem. Mater. 2001, 13, 3169-3183. [CrossRef]

56. Sing, K.S.W.; Everet, D.H.; Haul, R.A.W. Reporting physisorption data for gas-solid systems with special reference to the determination of surface-area and porosity. Pure Appl. Chem. 1985, 57, 603-619. [CrossRef]

57. Lu, W.; Liu, T.; Xie, L.; Tang, C.; Liu, D.; Hao, S.; Qu, F.; Du, G.; Ma, Y.; Asiri, A.M.; et al. In situ derived Co-B nanoarray: A high-efficiency and durable $3 \mathrm{~d}$ bifunctional electrocatalyst for overall alkaline water splitting. Small 2017, 13, 1700805. [CrossRef]

58. Gao, M.; Sheng, W.; Zhuang, Z.; Fang, Q.; Gu, S.; Jiang, J.; Yan, Y. Efficient water oxidation using nanostructured $\alpha$-nickel-hydroxide as an electrocatalyst. J. Am. Chem. Soc. 2014, 136, 7077-7084. [CrossRef]

59. Thenuwara, A.C.; Shumlas, S.L.; Attanayake, N.H.; Aulin, Y.V.; McKendry, I.G.; Qiao, Q.; Zhu, Y.; Borguet, E.; Zdilla, M.J.; Strongin, D.R. Intercalation of cobalt into the interlayer of birnessite improves oxygen evolution catalysis. ACS Catal. 2016, 6, 7739-7743. [CrossRef]

60. Zhou, T.; Cao, Z.; Zhang, P.; Ma, H.; Gao, Z.; Wang, H.; Lu, Y.; He, J.; Zhao, Y. Transition metal ions regulated oxygen evolution reaction performance of Ni-based hydroxides hierarchical nanoarrays. Sci. Rep. 2017, 7, 46154. [CrossRef]

61. Wang, X.; Zhuang, L.; He, T.; Jia, Y.; Zhang, L.; Yan, X.; Gao, M.; Du, A.; Zhu, Z.; Yao, X.; et al. Grafting cobalt diselenide on defective graphene for enhanced oxygen evolution reaction. iScience 2018, 7, 145-153. [CrossRef] [PubMed]

62. Hall, D.E. Alkaline Water Electrolysis Anode Materials. J. Electrochem. Soc. 1985, 132, 41C-48C. [CrossRef]

63. Wang, Y.; Zhou, T.; Jiang, K.; Da, P.; Peng, Z.; Tang, J.; Kong, B.; Cai, W.B.; Yang, Z.; Zheng, G. Reduced mesoporous $\mathrm{Co}_{3} \mathrm{O}_{4}$ nanowires as efficient water oxidation electrocatalysts and supercapacitor electrodes. Adv. Energy Mater. 2014, 4, 1400696. [CrossRef]

64. Schlesinger, M.; Lasia, A. Modeling of Impedance of Porous Electrodes, Modeling and Numerical Simulations; Springer: New York, NY, USA, 2009; pp. 67-137.

65. Bao, J.; Zhang, X.; Fan, B.; Zhang, J.; Zhou, M.; Yang, W.; Hu, X.; Wang, H.; Pan, B.; Xie, Y. Ultrathin spinel-structured nanosheets rich in oxygen deficiencies for enhanced electrocatalytic water oxidation. Angew. Chem. 2015, 127, 7507-7512. [CrossRef]

66. Aijaz, A.; Masa, J.; Rösler, C.; Xia, W.; Weide, P.; Botz, A.J.R.; Fischer, R.A.; Schuhmann, W.; Muhler, M. $\mathrm{Co} @ \mathrm{Co}_{3} \mathrm{O}_{4}$ encapsulated in carbon nanotube-grafted nitrogen-doped carbon polyhedra as an advanced bifunctional oxygen electrode. Angew. Chem. Int. Ed. 2016, 55, 4087-4091. [CrossRef] [PubMed]

67. Tang, H.; Prasad, K.; Sanjinès, R.; Schmid, P.E.; Lévy, F. Electrical and optical properties of $\mathrm{TiO}_{2}$ anatase thin films. J. Appl. Phys. 1994, 75, 2042-2047. [CrossRef]

68. Wang, Q.; Hu, W.; Huang, Y. Nitrogen-doped graphene anchored cobalt oxides efficiently bi-functionally catalyze both oxygen reduction reaction and oxygen revolution reaction. Int. J. Hydrog. Energy 2017, 42, 5899-5907. [CrossRef]

69. Huang, Y.B.; Zhang, M.; Liu, P.; Cheng, F.L.; Wang, L.S. $\mathrm{Co}_{3} \mathrm{O}_{4}$ supported on N, P-doped carbon as a bifunctional electrocatalyst for oxygen reduction and evolution reactions. Chin. J. Catal. 2016, 37, 1249-1256. [CrossRef]

70. Jung, J.I.; Risch, M.; Park, S.; Kim, M.G.; Nam, G.; Jeong, H.Y.; Shao-Horn, Y.; Cho, J. Optimizing nanoparticle perovskite for bifunctional oxygen electrocatalysis. Energy Environ. Sci. 2016, 9, 176-183. [CrossRef]

71. Masa, J.; Xia, W.; Sinev, I.; Zhao, A.; Sun, Z.; Grützke, S.; Weide, P.; Muhler, M.; Schuhmann, W. $\mathrm{Mn}_{\mathrm{x}} \mathrm{O}_{\mathrm{y}} / \mathrm{NC}$ and $\mathrm{Co}_{\mathrm{x}} \mathrm{O}_{\mathrm{y}} / \mathrm{NC}$ nanoparticles embedded in a nitrogen-doped carbon matrix for high-performance bifunctional oxygen electrodes. Angew. Chem. Int. Ed. 2014, 53, 8508-8512. [CrossRef]

(C) 2019 by the authors. Licensee MDPI, Basel, Switzerland. This article is an open access article distributed under the terms and conditions of the Creative Commons Attribution (CC BY) license (http://creativecommons.org/licenses/by/4.0/). 